\title{
More Than Brides Alliance: Baseline report, India
}

\author{
Sharmistha Basu \\ Rajib Acharya \\ Population Council \\ Andrea J. Melnikas \\ Population Council \\ Sajeda Amin \\ Population Council
}

Follow this and additional works at: https://knowledgecommons.popcouncil.org/departments_sbsr-pgy

Part of the Demography, Population, and Ecology Commons, Family, Life Course, and Society Commons, International Public Health Commons, and the Maternal and Child Health Commons How does access to this work benefit you? Let us know!

\section{Recommended Citation}

Basu, Sharmistha, Rajib Acharya, Andrea J. Melnikas, and Sajeda Amin. 2017. "More Than Brides Alliance: Baseline report, India." New York: Population Council. 


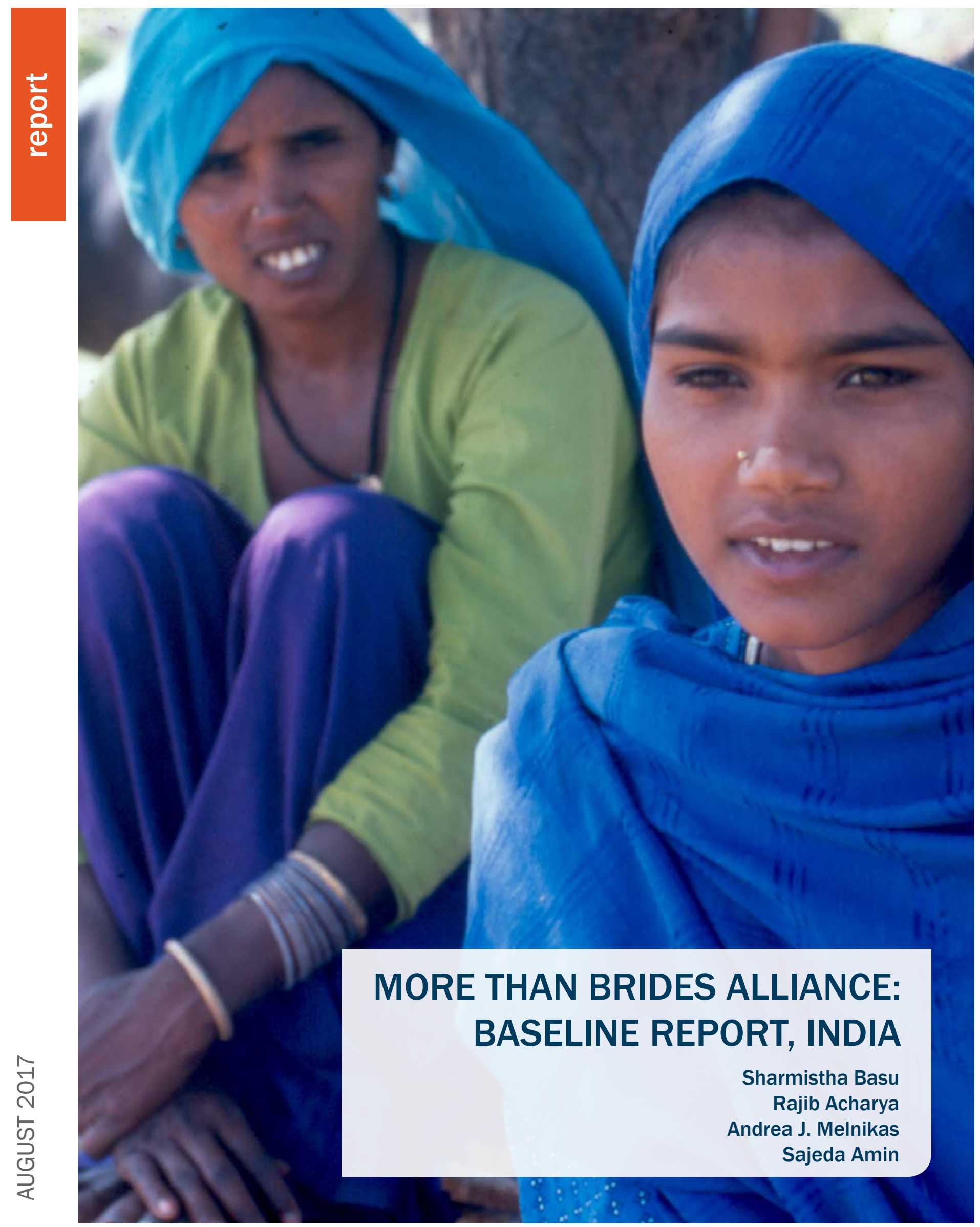

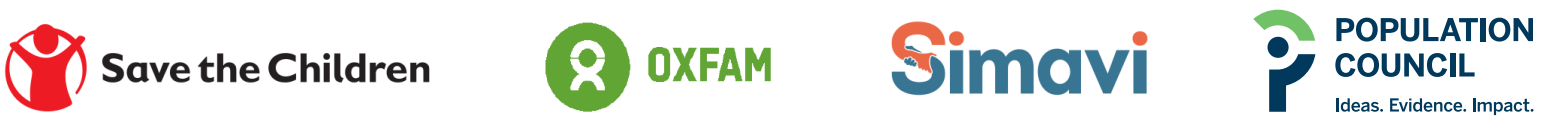




\section{Population
council \\ Ideas. Evidence. Impact.}

The Population Council confronts critical health and development issues-from stopping the spread of HIV to improving reproductive health and ensuring that young people lead full and productive lives. Through biomedical, social science, and public health research in 50 countries, we work with our partners to deliver solutions that lead to more effective policies, programs, and technologies that improve lives around the world. Established in 1952 and headquartered in New York, the Council is a nongovernmental, nonprofit organization governed by an international board of trustees.

\section{Population Council}

1 Dag Hammarskjold Plaza

New York, NY 10017

USA

Tel: +12123390500

Fax: +12127556052

email: pubinfo@popcouncil.org

popcouncil.org

Suggested citation: Basu, Sharmistha, Rajib Acharya, Andrea J. Melnikas, and Sajeda Amin. 2017. "More Than Brides Alliance: Baseline Report, India." New York: Population Council.

Photo credit: Population Council

The More Than Brides Alliance Baseline Reports are available for India, Malawi, Mali, Niger.

(C) 2017 The Population Council, Inc. 


\section{Table of Contents}

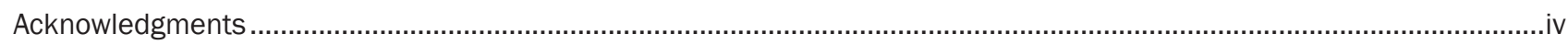

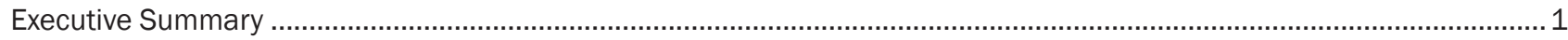

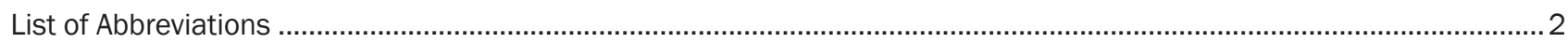

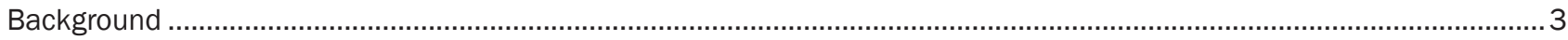

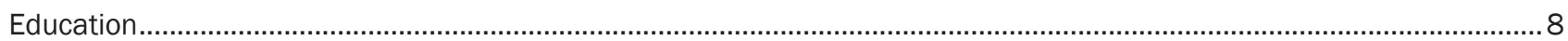

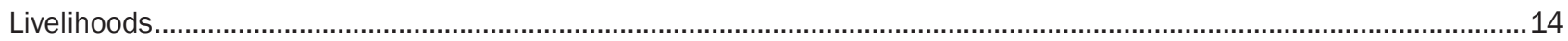

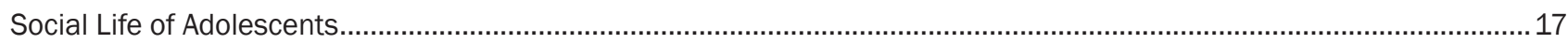

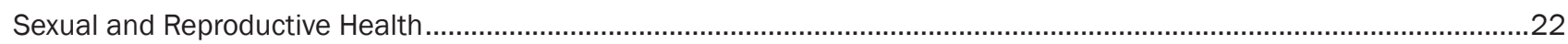

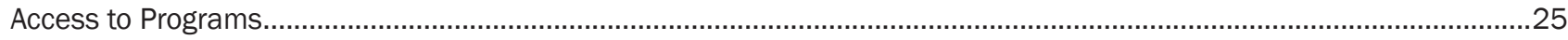

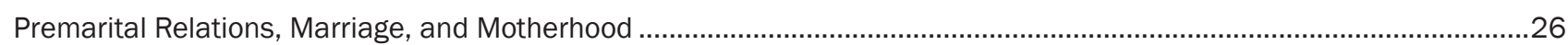

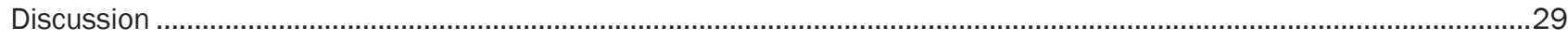

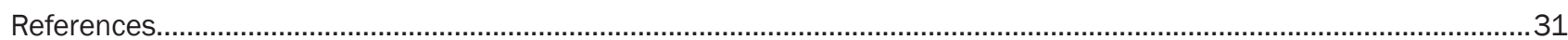




\section{Acknowledgments}

A number of individuals have contributed to the baseline report for India and we appreciate their efforts. We thank the members of the More Than Brides Alliance, including Save the Children Netherlands, Oxfam Novib, and Simavi. In India, Save the Children and Simavi are implementing programs to delay marriage and improve outcomes for adolescent girls in cooperation with local partners. We look forward to seeing the results from these interventions.

We also thank the Ministry of Foreign Affairs Netherlands for their support of the More Than Brides Alliance and of the research and evaluation component specifically.

Finally, we are grateful for the research participants, in particular the adolescent girls and young women who shared their experiences, thoughts, and ambitions with the research team. We thank them for their participation, without which this report would not be possible. 


\section{Executive Summary}

We conducted surveys of adolescent girls and young women aged 12-19 in nine districts in four states: Gaya and Sitamarhi (Bihar), Deoghar and Dumka (Jharkhand), Tonk and Jodhpur (Rajasthan), and Nuapada, Kandhamal, and Ganjam (Odisha). A total of 2,982 interviews were completed examining girls' experiences, including education, marriage and relationships, literacy and numeracy, livelihoods, and gender-equitable attitudes.

Overall, about 1 in 4 girls from Jharkhand (26\%), 1 in 6 in Bihar (17\%), and 1 in 13 in Odisha and Rajasthan (8\%) were married and living with their husband at the time of the interview. However, among girls aged 15-19, the proportions were much higher: $48.7 \%$ of girls aged $15-19$ in Jharkhand were currently married followed by $26.9 \%$ in Bihar, $12.9 \%$ in Rajasthan, and $12.6 \%$ in Odisha. We also found a large variation in the average age at marriage within these four study states: average age at marriage in Odisha was 17 , compared to 15 in Bihar and Jharkhand, and only 13 in Rajasthan. There were also interesting differences among states in the average age at cohabitation, suggesting that perhaps the cultural practice of gauna (the ceremony that marks a girl's physical move from her home to her husband's home) differs in each setting.

We found that school enrollment was nearly universal among girls in our study, except in Bihar where about 12 percent of adolescent girls were illiterate or had never been to school. Among all girls aged 12-19, the median years of school attained (highest standard/class successfully completed) was only six years in Bihar and eight years in the other three states. Despite high levels of schooling overall, school retention was an issue: only about three-fifths (55\%-63\%) of the adolescent girls aged $12-19$ were in school at the time of the interview.

Perhaps due in part to lower enrollment levels, we found that engagement in wage work was not uncommon among this group, even among younger adolescent girls (12-14 years). Among the younger respondents, 15\%-23\% reported that they had ever worked for wages and $4 \%-11 \%$ had worked for wages in the month before the survey. Among the older adolescents (15-19 years), over one-quarter (Rajasthan) to one-half (Odisha) were ever engaged in wage work and $7 \%-24 \%$ in the month before the survey. Occupational profiles of those who were engaged in wage work show that farming/agricultural work and unskilled daily wage work were the leading occupations among adolescent girls. Despite moderate levels of engagement in paid work, about two-fifths of adolescent girls from Bihar (39\%) and Odisha (37\%) report having access to personal cash savings in case of emergency, while about one-third from Rajasthan (34\%) reported so. Interestingly, in Jharkhand, many more adolescent girls compared to other states reported having access to personal cash savings (53\%).

In examining the social lives of these girls we found that very few girls $(2 \%-6 \%)$ were part of any adolescent group. Married girls were also much less likely to report having at least one friend compared to their unmarried peers: $87 \%-97 \%$ of unmarried girls compared to $57 \%-85 \%$ of married girls from the study states reported having at least one friend. These findings suggest that girls, particularly those who are married, may be socially isolated and programs should consider how best to locate and engage these girls.

The More Than Brides Alliance seeks to improve the lives of adolescent girls and includes activities across multiple domains (reproductive health, education, gender norms, and livelihoods, to name a few). Overall, most girls in these communities reported ever going to school, and early marriage varied from 1 in 4 in Jharkhand to 1 in 13 in Odisha and Rajasthan. We found that few girls were currently involved in any programs, despite demonstrated vulnerabilities (e.g., more than half of the sample was currently out of school) suggesting that there is a clear need for interventions to address vulnerabilities in this population. Findings from the baseline study will be used to evaluate changes over time that may be attributable to the MTBA intervention and to inform programmatic staff seeking to understand the populations they are serving. 


\section{List of Abbreviations}

$\begin{array}{ll}\text { CSE } & \text { Comprehensive Sexuality Education } \\ \text { CCT } & \text { Conditional Cash Transfer } \\ \text { LSE } & \text { Life Skills Education } \\ \text { MTBA } & \text { More Than Brides Alliance } \\ \text { NFHS } & \text { National Family Health Survey } \\ \text { SRHR } & \text { Sexual and Reproductive Health and Rights } \\ \text { STI } & \text { Sexually Transmitted Infection }\end{array}$




\section{Background}

India alone accounts for one-third of girls married before age 18 globally (UNICEF 2014). Recent National Family Health Survey data highlighted that more than one-quarter of women (27\%) aged 20-24 were still getting married before age 18 (IIPS 2016). Although child marriage is on the decline in India, the pace of decline is very slow with about one-fifth percentage point decline (21\%) in the past decade according to Census of India 2001 and 2011 (Office of the Registrar General and Census Commissioner, India n.d., a, n.d., b).

More recent data available from the National Family Health Survey (NFHS-4, 2015-16) highlight large declines in early marriage, defined as the percentage of girls married before age 18. Table 1 shows trends and variations in early marriage in the last decade for selected states of India. At the country level, overall there has been a decline of 21 percentage points (or 43\%) between NFHS-3 (2005-06) and NFHS-4 (2015-16). Wide variation by state is observed. In 8 of the 18 major states presented here, the decline in early marriage from $2005-06$ is more than $40 \%$ and these include large North Indian states where high numbers of child marriages used to take place (Uttar Pradesh 64\%, Rajasthan 46\%, and Madhya Pradesh 43\%, to name a few). In two other early-marriage states-Bihar and Jharkhand-the decline has been $40 \%$. In fact, according to NFHS-4, the five states with the highest prevalence of early marriage were: West Bengal (41\%), Bihar (39\%), Jharkhand (38\%), Rajasthan (35\%), and Assam (33\%). In most states, prevalence in urban areas was much lower than in rural areas.

The More Than Brides Alliance implements and evaluates the effectiveness of a range of interventions to delay child marriage, including education, economic opportunities, child promotion, SRHR services, community engagement, and others. In Mali and Niger, the Council is conducting a quasiexperimental matched study, and in India and Malawi a cluster randomized trial to evaluate whether and to what extent these child marriage interventions improve young people's ability to decide when to marry and pursue their sexual and reproductive health rights in a supportive environment.

\section{Programmatic evidence to reduce child marriage}

In India, there have been various interventions to curb the practice of child marriage through mass communications programs and by implementing the child marriage act. These interventions also used advocacy, communication initiatives, and conditional cash transfer schemes to address child marriage issues. Some of these interventions have been evaluated to show evidence as to what might work to delay marriage, but many were not.

TABLE 1. Percentage of women married before age 18 among women aged 20-24 years in selected states, 2005-06 and 2015-16

\begin{tabular}{|c|c|c|c|}
\hline & $\begin{array}{c}\text { NFHS-3 } \\
(2005-06)\end{array}$ & $\begin{array}{c}\text { NFHS-4 } \\
(2015-16)\end{array}$ & $\begin{array}{c}\text { Percentage } \\
\text { change } \\
\text { between the } \\
\text { surveys }\end{array}$ \\
\hline India & 47.4 & 26.8 & 43.4 \\
\hline Assam & 38.0 & 32.6 & 14.2 \\
\hline Bihar & 60.3 & 39.1 & 35.1 \\
\hline Gujarat & 38.7 & 24.9 & 35.6 \\
\hline Haryana & 39.8 & 18.5 & 53.5 \\
\hline $\begin{array}{l}\text { Himachal } \\
\text { Pradesh }\end{array}$ & 12.3 & 8.6 & 30.1 \\
\hline $\begin{array}{l}\text { Jammu and } \\
\text { Kashmir }\end{array}$ & 14.4 & 8.7 & 39.5 \\
\hline Jharkhand & 63.2 & 38.0 & 39.8 \\
\hline Karnataka & 41.2 & 23.2 & 43.7 \\
\hline Kerala & 15.4 & 7.6 & 50.6 \\
\hline Madhya Pradesh & 53.0 & 30.0 & 43.0 \\
\hline Maharashtra & 39.0 & 25.1 & 35.6 \\
\hline Odisha & 37.2 & 21.3 & 42.7 \\
\hline Punjab & 19.7 & 7.6 & 61.4 \\
\hline Rajasthan & 65.2 & 35.4 & 45.7 \\
\hline Tamil Nadu & 21.5 & 15.7 & 26.9 \\
\hline Uttarakhand & 22.6 & 13.9 & 38.5 \\
\hline Uttar Pradesh & 58.6 & 21.2 & 63.8 \\
\hline West Bengal & 53.3 & 40.7 & 23.6 \\
\hline
\end{tabular}


The Prohibition of Child Marriage Act, 2006 replaced the old legislation, namely the Child Marriage Restraint Act of 1929, and includes enabling provisions to prohibit child marriage, protect and provide relief to victims, and enhance punishment for those who abet, promote, or solemnize such marriage. It also calls for the appointment of Child Marriage Prohibition Officers to implement the Act. Various studies have highlighted that even after ten years, the implementation of the Act has been a challenge particularly because of failure of the state to appoint appropriate staff at state and district levels, and lack of convergence of information from various departments reporting child marriage and effective punitive action against offenders (HAQ Centre for Child Rights n.d.; MOWCD n.d.; NMEW and NRCW n.d.; Ghosh 2011; Singh 2013).

Advocacy and communication initiatives to address inegalitarian gender attitudes and mobilize communities to delay marriage have mostly been undertaken by NGOs. A few examples are the Prevention of Child Marriage Campaign ( $\mathrm{Bal}$ Vivaha Roktham Pahal) and Our Daughter's Right campaign (Aapani Dikari Ro Haq)-both in Rajasthan, and Bachpan Bachao Andolan in Jharkhand. None of these advocacy programs were evaluated to show evidence whether they were successful in arresting child marriage.

Programs have also been implemented by the Department of Education to keep girls in school, including the Kasturba Gandhi Balika Vidyalaya, the National Program for Education of Girls in the Elementary Level, and the National Scheme for Incentives to Girls for Secondary Education and the Free Bicycle scheme (Ministry of Human Resource Development n.d.; Ministry of Human Resource Development, Department of School Education and Literacy n.d.) in some states. However, in most of the cases there was no evidence on effectiveness of these government schemes in increasing secondary school enrollment or completion among girls.

Another type of program that the government invested in was conditional cash transfer (CCT) programs to arrest the practice. Conditional cash or noncash transfer (CCT) schemes aimed to delay age at marriage of girls by transferring cash incentives in the girl's/mother's name at various milestones in a girl's life, for example birth registration, school enrollment, completion of secondary education. Eventually the full amount was transferred on the provision that the girl reached age 18 and remained unmarried. Recent evaluation of a longterm CCT in Haryana, namely Apna Beti Apna Dhan, did not hold promise to delay marriage for girls (Nanda et al. 2016). Some NGO programs used integrated strategies, and one of the strategies was to impart life skills and reproductive health information to delay marriage, which showed positive change in age at marriage. Examples include the Development Initiative Supporting Healthy Adolescents (DISHA) program implemented by ICRW in Bihar and Jharkhand (Kanesathasan et al. 2008) and the Maharashtra life skills program (Pande et al. 2006.). However, none of these programs could establish a clear pathway through which the change was triggered.

\section{More Than Brides Alliance (MTBA)}

The More Than Brides Alliance (MTBA) is an alliance of several partners led by Save the Children, Netherlands and is an implementing program to reduce the prevalence of child marriage and its negative consequences for young women and girls in five countries. Other partners of the alliance are Oxfam Novib, Simavi, and the Population Council. The five countries in which the program that's named "Marriage: No Child's Play" is being implemented are: India, Malawi, Mali, Niger, and Pakistan. Broadly, the programs implemented by MTBA have defined five key result areas:

- Empowering at-risk and already-married adolescents, girls in particular, with life skills education (LSE), comprehensive sexuality education (CSE), and sexual and reproductive health and rights (SRHR) information.

- $\quad$ Providing alternatives to child marriage and mitigating the impact on married girls, through enhancing access to education, economic opportunities, and child protection systems for girls and their families.

- Increasing access to SRHR services for young people.

- $\quad$ Changing social norms.

- Influencing legal and policy frameworks.

In India, Save the Children and Simavi are working with several local partners (Agragami India, Asha-Odisha, BVHA, Charm, CINI, NEEDS, Shiv Shiksha Samiti Ranoli, Swati, VHAI, and Vikalp to implement the "Marriage: No Child's Play" program in four states-Bihar, Jharkhand, Odisha, and Rajasthan. The Population Council is the evaluation partner in the country.

\section{Study objectives}

The aims of this baseline study were to: 1) provide a benchmark against which changes resulting from the MTBA intervention may be measured at the midline and endline 
FIGURE 1. Baseline data collection areas

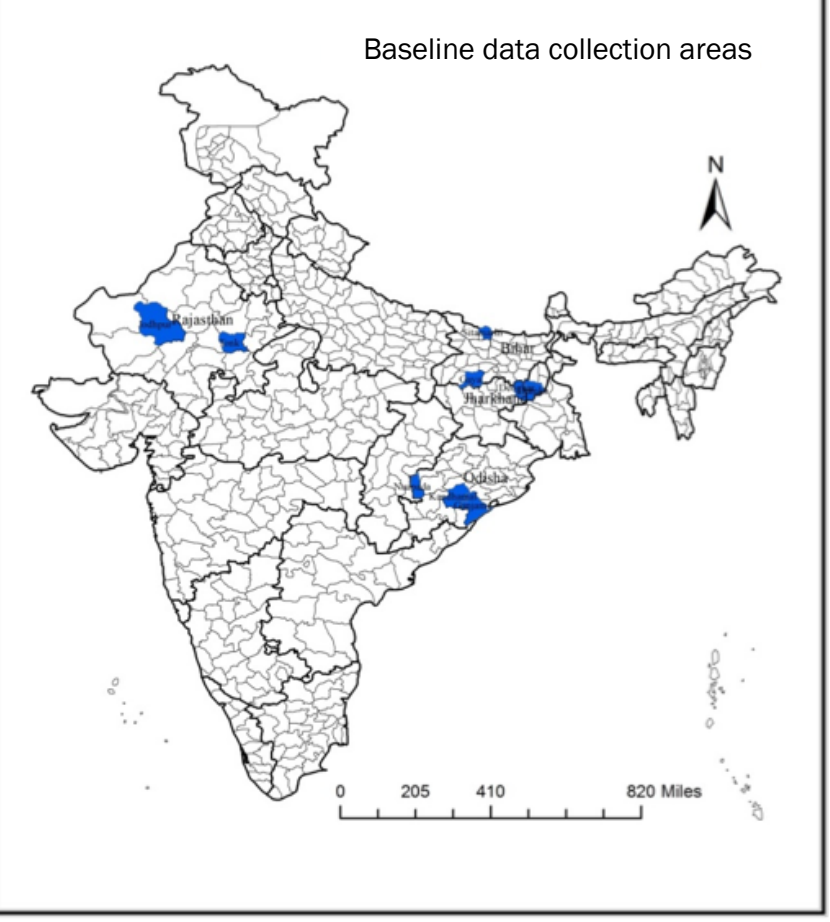

periods; 2) provide information about the current situation and context for adolescent girls in select states in India in order to inform the MTBA intervention; and 3) identify themes in need of further exploration through qualitative research.

\section{Study setting}

The study was conducted in rural areas of nine districts from four states-Bihar, Jharkhand, Rajasthan, and Odisha. Gaya and Sitamarhi from Bihar, Deoghar and Dumka from Jharkhand, Tonk and Jodhpur from Rajasthan, and Nuapada, Kandhamal, and Ganjam districts from Odisha were selected for the study.

\section{Study design}

The study was conducted among adolescent girls aged 1219 years. A mixed method design has been used to evaluate the program and includes a cluster randomized trial with cross-sectional surveys of adolescent girls aged 12-19 (married or unmarried) at three points in time-before the intervention began (baseline), at the midpoint of intervention (midline), and after the intervention is over (endline).
In order to provide opportunity to cover the entire program area without compromising the research, a wedge design was developed in which $50 \%$ of the control clusters would be available for program implementation after midline.

Randomization of village clusters ${ }^{1}$ (one or more villages with at least 120-150 households) was followed by baseline assessments that are comprised of both quantitative and qualitative methods. Qualitative data collection methods (from intervention areas only) were comprised of longitudinal in-depth interviews with selected peer educators, focus group discussions with girls aged 12-19 (married and unmarried separately) and parents of adolescent girls aged 12-19, and finally participant observation of training session and girls group formation and informal interactions with field program staff. This report does not provide data from qualitative assessments.

In the baseline, 104 village clusters (168 villages) were selected for evaluation and half were randomly allocated to control. Randomization was done post stratification by states. These clusters were equally distributed in four states (i.e., 26 in each). The baseline data collection included two components: household listing and survey of adolescent girls 12-19 years of age.

\section{Household listing}

Teams of two-a mapper (male) and a lister (female)mapped and listed 120-150 households in each village cluster and asked an adult member of the household if there were any adolescent girls aged 10-21. If there was one, the team collected information about age, education, marriage, childbearing, and engagement in work for pay. If the village was large, it was appropriately segmented for the household listing exercise and only one segment was selected for listing. A total of 16,106 households were listed prior to the main survey of 12-19-year-old adolescent girls.

\section{Survey of adolescent girls 12-19 years}

Following the household listing exercise, we randomly selected about 20-40 adolescent girls aged $12-19$ years from each of the selected village clusters irrespective of their marital status. In village clusters where more than 40 eligible girls were available, 40 were systematically selected; otherwise, all eligible girls were selected for interview. The survey probed various topics including background

\footnotetext{
1. If a village was smaller than 120-150 households, we created village clusters grouping the small village to the next one or more villages within the same Panchayat. Clusters were vetted by the partners.
} 
TABLE 2. Completed interviews by state

\begin{tabular}{|l|c|}
\hline State & Number of interviews completed \\
\hline Bihar & 754 \\
\hline Jharkhand & 731 \\
\hline Odisha & 721 \\
\hline Rajasthan & 776 \\
\hline Total & 2,982 \\
\hline
\end{tabular}

characteristics, education, and schooling experiences including a learning outcome test and vocational training. In addition, it also asked questions on adolescent girls' reproductive health knowledge and practices, marriage, sexual experiences, birth history, social context, connections, agency, gender attitudes, livelihoods, and migration experiences. At baseline, we attempted to interview 3,193 adolescent girls and completed 2,982 interviews (Table 2).

\section{Data Collection and Ethical Considerations}

Baseline quantitative data collection was conducted during November to December 2016. Study instruments were prepared in English, translated to Hindi and Odia, and pre-tested. A team of 59 interviewers was trained by Population Council staff for 10 days to conduct the survey in both Hindi and Odia speaking states. Separate training programs were conducted for Hindi and Odia speaking investigators. Training focused on interviewing method, details of the questionnaire, and research ethics, including issues of confidentiality and privacy. Each interview team consisted of four female and one male interviewer, and only female interviewers conducted the interviews with the respondents while the male interviewers ensured that the sampling scheme was followed, helped the female interviewers find households and maintain privacy, and provided technical support when needed. Three teams in each state were used to collect data simultaneously. In each state, data collection was completed in 30 days.

A field coordinator carried out the day-to-day monitoring of quality of data collection. In addition, the principal investigators made field visits to monitor and supervise data collection. We recognized the ethical concerns that could arise from the survey of girls and took special care to maintain the privacy of the interview and anonymity by not recording names and by conducting the interviews in complete privacy. As mentioned earlier, only female interviewers conducted the interviews to put female respondents at ease in responding. The Population Council's Institutional Review Board approved the protocol for this study.

\section{Data processing}

SurveyCTO, an Android-based mobile application for data collection, was used for collecting data using mobile tablets. Data were uploaded to a secure server every day in the evening during the month of data collection. Stata 14.1 was used to clean the data as well as perform the analysis. Data analysis primarily focused on state-level descriptive statistics for variables of interest.

TABLE 3. Key socio-demographic indicators of intervention and control areas

\begin{tabular}{|l|c|c|}
\hline $\begin{array}{l}\text { Key demographic } \\
\text { indicators }\end{array}$ & Intervention & Control \\
\hline Age (mean) & 15.1 & 15.0 \\
\hline Hindu (\%) & $86.7 * * *$ & 93.8 \\
\hline $\begin{array}{l}\text { Respondents } \\
\text { currently married } \\
\text { (\%) }\end{array}$ & 19.4 & 17.6 \\
\hline $\begin{array}{l}\text { Respondents } \\
\text { currently in } \\
\text { school }\end{array}$ & 57.7 & 61.0 \\
\hline $\begin{array}{l}\text { Age at marriage } \\
\text { (mean) }\end{array}$ & $14.5 *$ & 13.9 \\
\hline $\begin{array}{l}\text { Age at gauna } \\
\text { (mean) }\end{array}$ & 15.8 & 15.6 \\
\hline $\begin{array}{l}\text { Has an Adhar } \\
\text { card (\%) }\end{array}$ & 87.8 & 12.7 \\
\hline General category & $8.6 *$ & 26.1 \\
\hline $\begin{array}{l}\text { Lowest wealth } \\
\text { quintile }\end{array}$ & $22.1 * *$ & $\mathrm{~N}=1,498$ \\
\hline $\begin{array}{l}\text { Number of } \\
\text { respondents }\end{array}$ & $\mathrm{N}=1,484$ & \\
\hline
\end{tabular}

Note: The t-tests used: *, **, ***, are significant at $p<=0.05$, $p<=0.010$, and $p<=0.001$, respectively.

TABLE 4. Age distribution of adolescent girls by intervention and control areas

\begin{tabular}{|c|c|c|}
\hline Age & Intervention & Control \\
\hline 12 & 13.3 & 14.6 \\
\hline 13 & 16.3 & 15.6 \\
\hline 14 & 15.0 & 16.0 \\
\hline 15 & 11.9 & 13.2 \\
\hline 16 & 12.6 & 12.7 \\
\hline 17 & 10.5 & 11.0 \\
\hline 18 & 13.1 & 9.2 \\
\hline 19 & 7.4 & 7.7 \\
\hline $\begin{array}{l}\text { Number of } \\
\text { respondents }\end{array}$ & $\mathrm{N}=1,484$ & $\mathrm{~N}=1,498$ \\
\hline
\end{tabular}




\section{Socio-demographic characteristics of women}

\section{in control and intervention sites}

Table 3 compares the socio-demographic characteristics of the sample in intervention and control areas. Findings show that overall the intervention and control areas seem well balanced in terms of most background characteristics of adolescent girls, except for a few. Mean age of adolescent girls was 15 , the same in both intervention and control areas, and the majority of respondents were Hindus (87\%-93\%). We note that in the control areas there were significantly more Hindus than in the intervention areas. Similar percentages of adolescent girls, about one in five (18\%-19\%), were currently married in both areas. Statistically significant differences between intervention and control areas were, however, observed in terms of age at marriage (15 and 14 years, respectively) and percentages that belong to the general caste category ( $9 \%$ and $13 \%$, respectively) and those belonging to the lowest wealth quintile (22\% and $26 \%$, respectively).

Table 4 compares the age distributions of samples of adolescent girls in the intervention and control areas. The age distributions of adolescent girls in intervention and control areas are very similar. The percentage of adolescent girls who reported to be age 19 is lower in the sample. This may be due to "age heaping," i.e. preference for number five and zero, which in our case is age 20. 


\section{Education}

Keeping girls in school has been an important strategy in programs to delay marriage. This section examines educational attainment and school attendance among adolescents, type and quality of educational institutions, schooling experiences, educational aspirations, and literacy and numeracy skills in four study states.

\section{Educational attainment}

Findings presented in Table 5 reveal that school enrollment was nearly universal except in Bihar where about $12 \%$ of adolescent girls were illiterate or had never been to school. Among all girls aged 12-19, median years of school attained (highest standard/class successfully completed) was only six years in Bihar and eight years in the other three states. Table 5 also shows that retention in school was challenging: only about three-fifths (55\%-63\%) of adolescent girls aged 12-19 were in school at the time of the interview. Among all the adolescent girls who were married, about one-sixth (16\%) were currently attending school compared to $69 \%$ of the unmarried girls. Furthermore, married girls in our sample completed an average of seven years of schooling as opposed to eight years among the unmarried girls (not shown in tables).

\section{Reasons for nonenrollment or discontinuation}

In the baseline survey, questions were asked about the reasons for never enrolling in school and for discontinuation. We divided the cited reasons into several categorieseconomic reasons (work on the family farm or business; wage-earning work; family poverty, i.e., the family could not afford to keep the respondent in school); housework-related reasons (required for care of siblings or housework); attitude or perception-related reasons (unsafe to send children to school, education not considered necessary by respondent or parents, respondent's lack of interest); schoolrelated reasons (school located too far away, appropriate transport not available, poor school quality and infrastructure, poor quality of teaching, including corporal punishment perpetrated by teachers, lack of female teachers); and health-related reasons (health problems of respondent, illness or death of a family member).
Data presented in Tables 6 and 7 show that the key reasons for never going to school and for discontinuing education were attitude- or perception-related in all four states: $41 \%-60 \%$ cited these as reasons for not going to school ever, and an even higher percentage, 72\%-92\%, cited these as reasons for discontinuing schooling. Among such reasons, the most important one was respondents' lack of interest in studies or failure (31\%-41\% and 65\%-82\%, respectively, by those who never went to school and those who discontinued studies). Housework-related and economic reasons were the next important reasons cited by both groups. For example, 34\%-49\% of those who never went to school and $20 \%-31 \%$ of those who discontinued school cited housework-related reasons. No consistent pattern was found among those who discontinued school and reported marriage as a reason for discontinuation. As high as 31\% from Jharkhand and as low as 5\%-6\% from Rajasthan and Odisha cited marriage as a reason for school discontinuation. One in seven girls (15\%) from Bihar cited marriage as a reason for discontinuation. 
TABLE 5. Percentage distribution of adolescents by years of schooling successfully completed, median years of schooling, and percentage currently in school and ever been to school

\begin{tabular}{|l|c|c|c|c|}
\hline Educational attainment (\%) & Bihar & Jharkhand & Odisha & Rajasthan \\
\hline None $^{1}$ & 11.9 & 5.3 & 4.9 & 6.7 \\
\hline 1-4 years & 14.5 & 7.3 & 3.5 & 6.6 \\
\hline 5-7 years & 37.4 & 36.7 & 32.5 & 31.2 \\
\hline 8-9 years & 26.5 & 38.4 & 32.0 & 36.1 \\
\hline 10-11 years & 6.6 & 9.4 & 21.6 & 11.9 \\
\hline 12+ years & 3.1 & 2.9 & 5.6 & 7.6 \\
\hline Median years of schooling & 6.0 & 8.0 & 8.0 & 8.0 \\
\hline Currently in school & 63.3 & 54.5 & 57.8 & 61.6 \\
\hline Number of respondents & 754 & 731 & 721 & 776 \\
\hline
\end{tabular}

${ }^{1}$ Includes nonliterate and literate with no formal schooling.

TABLE 6. Percentage of adolescent girls who never attended school by reasons for never attending

\begin{tabular}{|c|c|c|c|c|}
\hline Reasons for never attending school & Bihar & Jharkhand & Odisha & Rajasthan \\
\hline \multicolumn{5}{|l|}{ Economic reasons } \\
\hline Required for work on farm/family business & 10.7 & (12.5) & $(5.7)$ & $(8.7)$ \\
\hline Required for work for payment in cash/kind & 4.0 & $(18.8)$ & $(11.4)$ & $(2.2)$ \\
\hline Family could not afford it (cost too much) & 8.0 & $(12.5)$ & $(20.0)$ & $(6.5)$ \\
\hline At least one economic reason & 20.0 & $(43.8)$ & $(31.4)$ & $(13.0)$ \\
\hline \multicolumn{5}{|l|}{ Housework-related reasons } \\
\hline Required for household work & 37.3 & $(31.3)$ & $(42.9)$ & $(30.4)$ \\
\hline Required for care of siblings & 6.7 & $(6.3)$ & $(17.1)$ & $(8.7)$ \\
\hline At least one housework-related reason & 38.7 & $(34.4)$ & $(48.6)$ & $(37.0)$ \\
\hline \multicolumn{5}{|c|}{ Attitude and perception of parents and adolescents } \\
\hline Not safe to send girls to school & 2.7 & $(0.0)$ & $(5.7)$ & $(0.0)$ \\
\hline $\begin{array}{l}\text { Education not considered necessary } \\
\text { (parents) }\end{array}$ & 32.0 & $(15.6)$ & $(22.9)$ & $(21.7)$ \\
\hline Respondents not interested in studies & 33.3 & $(31.3)$ & $(40.0)$ & $(41.3)$ \\
\hline $\begin{array}{l}\text { At least one attitude/perception-related } \\
\text { reason }\end{array}$ & 60.0 & $(40.6)$ & $(57.1)$ & $(54.4)$ \\
\hline \multicolumn{5}{|l|}{ School-related reasons } \\
\hline School too far away/transport not available & 12.0 & $(12.5)$ & $(5.7)$ & $(10.9)$ \\
\hline $\begin{array}{l}\text { Poor quality of education/teaching, lack } \\
\text { of female teachers, and punishment by } \\
\text { teachers }\end{array}$ & 1.3 & $(3.1)$ & $(8.6)$ & $(4.4)$ \\
\hline At least one school-related reason & 13.3 & (15.6) & $(11.4)$ & $(15.2)$ \\
\hline \multicolumn{5}{|l|}{ Health } \\
\hline Respondent's illness & 2.7 & (3.1) & $(5.7)$ & $(0.0)$ \\
\hline Illness or death of a family member & 6.7 & $(12.5)$ & $(0.0)$ & $(0.0)$ \\
\hline Health-related reasons & 9.3 & $(15.6)$ & $(5.7)$ & $(0.0)$ \\
\hline Got married & 1.3 & (3.1) & $(0.0)$ & $(0.0)$ \\
\hline Number who never attended school & 75 & 32 & 35 & 46 \\
\hline
\end{tabular}

Note: Figures in parentheses based on $25-49$ cases. 
TABLE 7. Percentage of adolescent girls who discontinued schooling by reasons

\begin{tabular}{|c|c|c|c|c|}
\hline Reasons for school discontinuation & Bihar & Jharkhand & Odisha & Rajasthan \\
\hline \multicolumn{5}{|l|}{ Economic reasons } \\
\hline Required for work on farm/family business & 3.0 & 7.0 & 7.4 & 8.3 \\
\hline Required for work for payment in cash/kind & 1.5 & 5.3 & 5.9 & 1.6 \\
\hline Family could not afford it (cost too much) & 14.4 & 9.3 & 30.5 & 7.9 \\
\hline At least one economic reason & 18.3 & 19.7 & 40.1 & 16.7 \\
\hline \multicolumn{5}{|l|}{ Housework-related reasons } \\
\hline Required for household work & 22.8 & 19 & 29 & 25.8 \\
\hline Required for care of siblings & 5.4 & 2.7 & 6.3 & 4.8 \\
\hline At least one housework-related reason & 25.7 & 20.3 & 30.9 & 28.2 \\
\hline \multicolumn{5}{|l|}{ Attitude and perception of parents and adolescents } \\
\hline Not safe to send girls to school & 2.0 & 1.7 & 0.0 & 3.2 \\
\hline Education not considered necessary (parents) & 23.3 & 15.3 & 29.0 & 16.3 \\
\hline $\begin{array}{l}\text { Respondents not interested in studies } \\
\text { including failure }\end{array}$ & 65.3 & 65.7 & 81.8 & 78.2 \\
\hline $\begin{array}{l}\text { At least one attitude/perception-related } \\
\text { reason }\end{array}$ & 77.2 & 72.3 & 92.2 & 82.9 \\
\hline \multicolumn{5}{|l|}{ School-related reasons } \\
\hline School too far away/transport not available & 11.4 & 11.7 & 16.0 & 28.6 \\
\hline $\begin{array}{l}\text { Poor quality of education/teaching, lack of } \\
\text { female teachers, and punishment by teachers }\end{array}$ & 5.0 & 3.0 & 10.8 & 2.8 \\
\hline $\begin{array}{l}\text { Problem in admission/paperwork related to } \\
\text { admission }\end{array}$ & 0.0 & 1.7 & 1.5 & 0.8 \\
\hline At least one school-related reason & 16.3 & 15.7 & 27.1 & 31.4 \\
\hline \multicolumn{5}{|l|}{ Health } \\
\hline Respondent's illness & 4.0 & 3.0 & 7.8 & 6.3 \\
\hline Illness or death of a family member & 10.4 & 14.3 & 8.2 & 5.6 \\
\hline Health-related reasons & 14.4 & 17.3 & 16.0 & 11.5 \\
\hline Got married & 15.3 & 31.0 & 6.3 & 4.8 \\
\hline Number who discontinued schooling & 202 & 300 & 269 & 252 \\
\hline
\end{tabular}

Note: Figures in parentheses based on 25-49 cases.

\section{Educational aspiration}

In the baseline survey, adolescent girls who were studying in school at the time of the interview were asked about their own and parental educational aspirations regarding their education (i.e., the class up to which they would like to study or their parents want them to study).

Findings reveal that a large proportion of the adolescent girls from Bihar and Odisha-about one-third-aspired to pursue a bachelor's degree (Bihar 31\%, Odisha 34\%), followed by one-quarter for completing Class 10 (Bihar 24\%, Odisha 21\%). Different patterns were observed in Jharkhand and Rajasthan, though. In Jharkhand, more than one-quarter (29\%) reported that they would like to complete Class 10 fol- lowed by about one-quarter (24\%) who aspired to complete a bachelor's degree and one-fifth (20\%) who want to study up to class 12. In Rajasthan, however, completing class 12 was reported by over one-quarter (27\%), while one in five girls or more aspired to complete a bachelor's degree (19\%) or higher (22\%) (Table 8).

Adolescent girls' parents' aspirations (as reported by the adolescents) largely matched with their own, with most girls reporting their parents want them to continue to study as much as they want (45\% in Rajasthan and about 30\% in the remaining three states). Nearly one-quarter (10\% in Rajasthan) of adolescent girls reported that their parents wanted them to complete secondary school. A significant minority did not know their parents' aspirations for them (12\%-18\%) (Table 8). 
TABLE 8. Percentage of adolescent girls who were studying at the time of the interview by level of education they aspire to complete and their parents aspire for them to complete

\begin{tabular}{|l|c|c|c|c|}
\hline Educational aspirations (\%) & Bihar & Jharkhand & Odisha & Rajasthan \\
\hline Class up to which adolescent girls would like to study & \multicolumn{4}{|l|}{} \\
\hline Less than Class 10 & 5.7 & 5.8 & 1.2 & 4.2 \\
\hline Class 10 & 23.9 & 28.9 & 21.3 & 27.4 \\
\hline Class 12 & 18.9 & 20.1 & 15.3 & 0.0 \\
\hline Vocational & 0.2 & 0.0 & 1.2 & 18.6 \\
\hline Bachelor's degree & 30.8 & 24.4 & 34.1 & 22.4 \\
\hline Higher than bachelor's degree & 7.3 & 6.5 & 6.5 & 16.5 \\
\hline As far as she likes & 11.3 & 12.3 & 18.7 & 1.4 \\
\hline Don't know & 1.8 & 2.1 & 1.7 & 3.8 \\
\hline Class up to which adolescent girl's parents would like her to study & & & 9.4 \\
\hline Less than Class 10 & 5.7 & 5.3 & 2.2 & 17.6 \\
\hline Class 10 & 22.4 & 21.1 & 23.5 & 0.0 \\
\hline Class 12 & 12.2 & 15.8 & 10.6 & 7.3 \\
\hline Vocational & 0.0 & 0.0 & 1.0 & 4.8 \\
\hline Bachelor's degree & 11.9 & 11.1 & 11.3 & 44.8 \\
\hline Higher than bachelor's degree & 1.7 & 0.8 & 1.4 & 0.8 \\
\hline As far as she likes & 29.6 & 30.2 & 30.5 & 11.5 \\
\hline Parents don't want her to study & 2.1 & 0.8 & 1.4 & 478 \\
\hline Don't know & 14.4 & 15.1 & 18.2 & 417 \\
\hline Number currently attending school & 477 & 398 & & \\
\hline
\end{tabular}

\section{Learning outcomes (literacy and numeracy)}

All respondents aged 12-19 were asked to participate in tests of their literacy and numeracy skills. Literacy was assessed by asking respondents to read one sentence in either Hindi or Odia. Numeracy was assessed through a series of questions that ranged from difficult to easy, including number recognition, simple mathematical operations, conversion of units, and geometry questions, for example. We present here the findings for the literacy test and test of number recognition and simple mathematical operations for three groups who have completed 1-5 years, 6-8 years, and 9 or more years of education.

As expected, in all study states those who completed more years of schooling displayed progressively better learning outcomes. For example, among those who completed 5 or less years of schooling $29 \%-42 \%$ could read at least one of the two sentences in vernacular, which sharply increased to $63 \%-85 \%$ among those who completed $6-8$ years of schooling and to $94 \%-98 \%$ among those who had completed 9 or more years of schooling. As for their ability to solve a division problem, these percentages for three groups are $12 \%-33 \%$, 37\%-62\%, and 51\%-82\%, respectively. Overall, the learning outcomes have been poor, and wide state-level variations exist. For example, Bihar showed consistently better performance in mathematics compared to all other states. Far fewer could correctly do harder mathematical problems-e.g., word problems of mathematical operations, conversion from grams to kilograms, and solving profit percentage problems and geometry and fraction problems (data not shown in table). 
TABLE 9. Percentage of adolescents who could successfully complete literacy and numeracy tests according to years of education completed and state

\begin{tabular}{|c|c|c|c|c|}
\hline Literacy and numeracy levels (\%) & Bihar & Jharkhand & Odisha & Rajasthan \\
\hline \multicolumn{5}{|c|}{ Completed $1-5$ years of education } \\
\hline \multicolumn{5}{|l|}{ Literacy levels } \\
\hline $\begin{array}{l}\text { Can read at least one of the two sentences in } \\
\text { Hindi/Odia }\end{array}$ & 39.1 & 29.0 & 32.4 & 41.7 \\
\hline Required for work for payment in cash/kind & 1.5 & 5.3 & 5.9 & 1.6 \\
\hline Family could not afford it (cost too much) & 14.4 & 9.3 & 30.5 & 7.9 \\
\hline At least one economic reason & 20.0 & $(43.8)$ & $(31.4)$ & $(13.0)$ \\
\hline \multicolumn{5}{|l|}{ Numeracy levels } \\
\hline Able to identify missing numbers & 68.1 & 56.5 & 50.0 & 62.6 \\
\hline Able to order numbers (descending) & 58.0 & 46.0 & 55.9 & 51.3 \\
\hline Able to solve one of the addition problems & 80.2 & 70.2 & 67.6 & 57.4 \\
\hline Able to solve one of the subtraction problems & 62.8 & 50.8 & 42.6 & 53.9 \\
\hline Able to solve one of the multiplication problems & 43.5 & 29.8 & 23.5 & 29.6 \\
\hline Able to solve one of the division problems & 33.3 & 15.3 & 11.8 & 15.7 \\
\hline Number who completed $1-5$ years of education & 207 & 124 & 68 & 115 \\
\hline \multicolumn{5}{|c|}{ Completed $6-8$ years of education } \\
\hline \multicolumn{5}{|l|}{ Literacy levels } \\
\hline $\begin{array}{l}\text { Can read at least one of the two sentences in } \\
\text { Hindi/Odia }\end{array}$ & 77.6 & 63.0 & 77.9 & 85.3 \\
\hline \multicolumn{5}{|l|}{ Numeracy levels } \\
\hline Able to identify missing numbers & 90.6 & 82.1 & 85.6 & 94.6 \\
\hline Able to order numbers (descending) & 83.2 & 70.9 & 73.6 & 87.4 \\
\hline Able to solve one of the addition problems & 95.1 & 91.3 & 88.6 & 72.2 \\
\hline Able to solve one of the subtraction problems & 88.1 & 82.4 & 78.6 & 85.9 \\
\hline Able to solve one of the multiplication problems & 74.1 & 60.5 & 58.2 & 64.7 \\
\hline Able to solve one of the division problems & 62.2 & 39.8 & 37.1 & 45.2 \\
\hline $\begin{array}{l}\text { Number who completed } 6-8 \text { years of } \\
\text { education }\end{array}$ & 286 & 392 & 299 & 334 \\
\hline \multicolumn{5}{|c|}{ Completed 9 or more years of education } \\
\hline \multicolumn{5}{|l|}{ Literacy levels } \\
\hline $\begin{array}{l}\text { Can read at least one of the two sentences in } \\
\text { Hindi/Odia }\end{array}$ & 94.2 & 94.9 & 94 & 97.5 \\
\hline \multicolumn{5}{|l|}{ Numeracy levels } \\
\hline Able to identify missing numbers & 97.7 & 93.2 & 93.1 & 97.5 \\
\hline Able to order numbers (descending) & 91.8 & 86.4 & 81.2 & 93.8 \\
\hline Able to solve one of the addition problems & 100.0 & 100.0 & 95.0 & 73.1 \\
\hline Able to solve one of the subtraction problems & 97.1 & 96.6 & 89.7 & 93.5 \\
\hline Able to solve one of the multiplication problems & 91.2 & 91.5 & 76.8 & 77.8 \\
\hline Able to solve one of the division problems & 81.9 & 68.2 & 51.1 & 62.2 \\
\hline $\begin{array}{l}\text { Number who completed } 9 \text { or more years of } \\
\text { education }\end{array}$ & 171 & 176 & 319 & 275 \\
\hline
\end{tabular}


63.3 Bihar

54.5 Jharkhand

57.8 odisna

Girls 12-19 currently enrolled in school (\%)

61.6 Rajasthan

22.6 вher

34.5 hararkand

23.6 odisha

Girls report being

harassed in school (\%)

19.6 Rajasthan
6.7 Bihar
$7.3 \quad$ Jharkhand
2 education completed
(among ever-attended school)

7.8 Rajasthan 


\section{Livelihoods}

This section of the report focuses on the wage-earning activities of adolescents, their occupations, and vocational skills training. Adolescent girls were asked a number of questions to assess if they ever participated in wage work (cash or kind) during the month preceding the interview and the type of occupation in which they were engaged. In Table 10 we present data on work participation by respondent's current age, which allows us to understand the situation of child labor in the state. Data as presented in Table 10 reveal that a significant number of girls aged 12-14 work for wages (15\%-23\%) implying that in all these states child labor is a major concern. Among adolescents aged 15-19, participation in wage work (either in the form of cash or kind) was highest in Odisha (48\%) and lowest in Rajasthan (26\%). Engagement in wage work during the month before the survey was low and followed the same pattern for both age groups-Odisha (11\%-24\%) being the highest and Bihar $(6 \%-7 \%)$ reporting the lowest. Even by this indicator, between $4 \%$ and $11 \%$ of those below 15 years of age were currently working for wages. Table 10 further reveals that the majority of those who were engaged in wage work during the last month were engaged in farm or agricultural work (25\% and 38\% in Odisha and Bihar, and 53\% and $60 \%$ in Jharkhand and Rajasthan, respectively), followed by informal-sector jobs as daily wage laborers (59\% in Odisha, about 25\% in Jharkhand and Rajasthan, and 15\% in Bihar). The pattern of adolescent engagement in wage occupation was very different in Odisha from the other three states. Among the four states, mean hours of wage work in the week prior to the interview was highest in Odisha (34 hours) and lowest in Bihar (18 hours).

TABLE 10. Percentage of adolescent girls aged 12-19 engaged in paid work, occupation, and mean hours worked

\begin{tabular}{|c|c|c|c|c|}
\hline Economic activity & Bihar & Jharkhand & Odisha & Rajasthan \\
\hline \multicolumn{5}{|c|}{ Adolescent girls aged 12-14 engaged in wage work (either cash or kind) } \\
\hline Ever worked & 20.3 & 18.9 & 23.0 & 15.4 \\
\hline $\begin{array}{l}\text { Worked during the one month prior } \\
\text { to the interview }\end{array}$ & 6.2 & 9.2 & 11.0 & 4.3 \\
\hline Number of respondents & 389 & 349 & 291 & 325 \\
\hline \multicolumn{5}{|c|}{ Adolescent girls aged 15-19 engaged in wage work (either cash or kind) } \\
\hline Ever worked & 29.9 & 35.5 & 48.1 & 26.2 \\
\hline $\begin{array}{l}\text { Worked during the one month prior } \\
\text { to the interview }\end{array}$ & 6.6 & 15.2 & 24.4 & 9.1 \\
\hline Number of respondents & 365 & 382 & 430 & 451 \\
\hline \multicolumn{5}{|c|}{ Main occupation (paid work for cash) in the one month prior to the interview } \\
\hline Teacher & $(8.3)$ & 4.4 & 4.4 & 0.0 \\
\hline Service & $(2.0)$ & 0.0 & 0.7 & 0.0 \\
\hline Business & $(2.1)$ & 0.0 & 0.7 & 0.0 \\
\hline Shopkeeper & $(2.1)$ & 0.0 & 0.0 & 0.0 \\
\hline Farmer/agricultural work & $(37.5)$ & 53.3 & 24.8 & 60.0 \\
\hline Cottage industry & $(16.7)$ & 16.7 & 2.9 & 1.8 \\
\hline Tailoring & $(16.7)$ & 2.2 & 7.3 & 14.5 \\
\hline Daily wage laborer & $(14.6)$ & 23.3 & 59.1 & 23.6 \\
\hline $\begin{array}{l}\text { Mean hours worked in the week } \\
\text { prior to the interview }\end{array}$ & $(18.0)$ & 27.4 & 34.3 & 21.8 \\
\hline $\begin{array}{l}\text { Number aged } 12-19 \text { engaged in } \\
\text { paid work for cash in the one month } \\
\text { prior to the interview }\end{array}$ & 48 & 90 & 137 & 55 \\
\hline
\end{tabular}


TABLE 11. Percentage of adolescent girls aged 15-19 who ever attended a vocational training program, type of program attended, and type of institution that conducted the course

\begin{tabular}{|c|c|c|c|c|}
\hline Participation in vocational training & Bihar & Jharkhand & Odisha & Rajasthan \\
\hline $\begin{array}{l}\text { Ever attended a vocational training } \\
\text { program conducted by government/ } \\
\text { private/NGO }\end{array}$ & 12.3 & 10.7 & 6.3 & 4.4 \\
\hline $\begin{array}{l}\text { Number of respondents aged } \\
15-19\end{array}$ & 365 & 382 & 430 & 451 \\
\hline \multicolumn{5}{|c|}{ Types of programs/courses last attended/completed } \\
\hline Tailoring & $(77.8)$ & $(61.0)$ & $(81.5)$ & * \\
\hline Fashion design & $(0.0)$ & $(2.4)$ & $(0.0)$ & * \\
\hline Typing/shorthand & $(2.2)$ & $(0.0)$ & $(0.0)$ & * \\
\hline Computer training & (11.1) & $(14.6)$ & $(7.4)$ & * \\
\hline Handicrafts/painting/embroidery & $(4.4)$ & $(12.2)$ & $(0.0)$ & * \\
\hline Beauty parlor/salon & $(4.4)$ & $(4.9)$ & $(0.0)$ & * \\
\hline Others & $(0.0)$ & $(4.9)$ & $(11.1)$ & * \\
\hline \multicolumn{5}{|c|}{ Type of institution that conducted the course } \\
\hline Government & $(28.9)$ & $(61.0)$ & $(25.9)$ & * \\
\hline Private/NGO & $(73.3)$ & $(43.9)$ & $(77.8)$ & * \\
\hline $\begin{array}{l}\text { Number who ever attended a } \\
\text { vocational training aged 15-19 }\end{array}$ & 45 & 41 & 27 & 20 \\
\hline
\end{tabular}

Note: "Others" category includes pickle making, jam making, and making incense sticks. Figures in parentheses are based on $25-49$ cases. *Percentages not shown, based on less than 25 cases.

\section{Participation in vocational training}

Tables 11 and 12 present data on the experience and preferences of adolescent girls aged 15-19 in joining a vocational training program. Findings reveal that very few adolescents had participated in a vocational training program conducted by the government or private agencies or NGOs. Only $12 \%$ and $11 \%$ of girls from Bihar and Jharkhand, and 4\%-6\% from Odisha and Rajasthan attended a vocational training course. These programs were mainly conducted by private-sector institutions or NGOs (except in Jharkhand where government-run programs predominated). Data on the type of program last attended/completed show that the list was dominated by tailoring $(61 \%-82 \%)$ followed by computer training $(7 \%-15 \%)$.

\section{Preferences for participating in vocational training programs}

Table 12 highlights adolescent girls' preferences for participation in vocational training activity by the trade they would prefer to join. The majority of adolescent girls aged 15-19 were interested in participating in a vocational training program in the next one year, if supported. About three-quarters from both Odisha and Rajasthan (Odisha 76\%, Ra- jasthan 74\%) and 87\%-88\% from Bihar and Jharkhand reported that they were interested in participating in a vocational training program in the next one year. Again, an overwhelming proportion of girls reported that they would prefer to receive training in tailoring (85\%-97\%). This was followed by a preference for computer training (23\%-29\%), handicrafts/embroidery (15\%-19\%), beauty parlor/salon (1\%-16\%), etc. 
TABLE 12. Percentage of adolescent girls aged 12-19 interested in participating in vocational training programs

\begin{tabular}{|l|c|c|c|c|}
\hline $\begin{array}{l}\text { Willingness to participate in } \\
\text { vocational training program }\end{array}$ & Bihar & Jharkhand & Odisha & Rajasthan \\
\hline $\begin{array}{l}\text { Interested in participating in } \\
\text { vocational training program in the } \\
\text { next one year, if supported }\end{array}$ & 87.4 & 87.7 & 76.3 & 74.1 \\
\hline $\begin{array}{l}\text { Number of respondents aged } \\
\text { 15-19 }\end{array}$ & 365 & 382 & 430 & 451 \\
\hline Types of programs in which respondents preferred to participate & \multicolumn{3}{|l|}{} \\
\hline Tailoring & 93.7 & 97.3 & 84.8 & 91.9 \\
\hline Fashion design & 6.0 & 3.3 & 5.2 & 5.7 \\
\hline $\begin{array}{l}\text { Handicrafts/painting/embroidery/ } \\
\text { cooking }\end{array}$ & 18.5 & 18.6 & 19.4 & 15.0 \\
\hline Masonry/plumbing & 8.5 & 8.4 & 1.8 & 0.9 \\
\hline Electric work/auto mechanics & 11.9 & 9.0 & 3.3 & 20.1 \\
\hline Typing/shorthand/English language & 2.8 & 5.7 & 13.1 & 24.9 \\
\hline Computer training & 23.2 & 23.3 & 29.3 & 2.7 \\
\hline Nurse's aid & 1.6 & 4.5 & 14.3 & 3.9 \\
\hline Driving & 0.0 & 0.6 & 2.1 & 16.2 \\
\hline Beauty parlor/salon & 11.9 & 8.4 & 1.2 & 2.4 \\
\hline Other & 0.9 & 2.1 & 10.1 & 334 \\
\hline $\begin{array}{l}\text { Number interested in participating } \\
\text { in a vocational training program } \\
\text { aged 15-19 }\end{array}$ & 319 & 335 & 328 & \\
\hline
\end{tabular}

Note: Column totals may exceed $100 \%$ due to multiple responses. "Other" includes dance, singing, horticulture, and agriculture.

\subsection{Bhar}

12.3 mathana

19.0 odstan

7.1
Rajasthan

\section{5 sinar}

53.4 harkhand

Girls report saving money for the future (\%)
37.3 odisha

34.3 Rajasthan 


\section{Social Life of Adolescents}

In the baseline, we also asked adolescents a number of questions on whether they have friends, watch television, have access to mobile phones, have access to money, whether they are a member of a group, and their genderrole attitudes. Figures 2, 3, and 4, and Tables 13-15 present data on the above aspects of adolescents' social life.

\section{Peer network}

Peers are an important influence in adolescent girls' lives and are also often a source of information and support. Since, typically, number and pattern of friendships change after a girl gets married, we have presented data on peer networks separately for unmarried (Figure 2) and married (Figure 3) girls. Overall, although many married and unmarried girls reported at least one friend, many more unmarried than married girls reported so. For example, $87 \%-97 \%$ of unmarried girls compared to $57 \%-85 \%$ of married girls from the study states reported at least one friend. Far fewer, irrespective of their marital status, reported at least one male friend (10\%-58\% among unmarried girls and 5\%-44\% among married girls). There are, however, large state variations with more girls from Odisha than the rest reporting male friends (44\% and 58\% in Odisha among married and unmarried adolescents, respectively).

\section{Exposure to mass media and access to mobile phones}

Access to mobile phones (i.e., owning or having access to) among adolescent girls aged $12-19$ is quite high in all four states, from $76 \%$ in Odisha to $88 \%$ in Rajasthan (Figure 4). However, only $8 \%-12 \%$ of girls reported that they owned a mobile phone; most have access to a phone owned by someone else in the household (data not shown in the figure). Surprisingly, the proportion regularly watching television in the week prior to the interview is low, from $22 \%-50 \%$ in four states, with the highest prevalence in Odisha (50\%), followed by Rajasthan (45\%), Jharkhand (28\%), and Bihar (22\%).

FIGURE 2. Percentage of unmarried adolescent girls having female friends and male friends

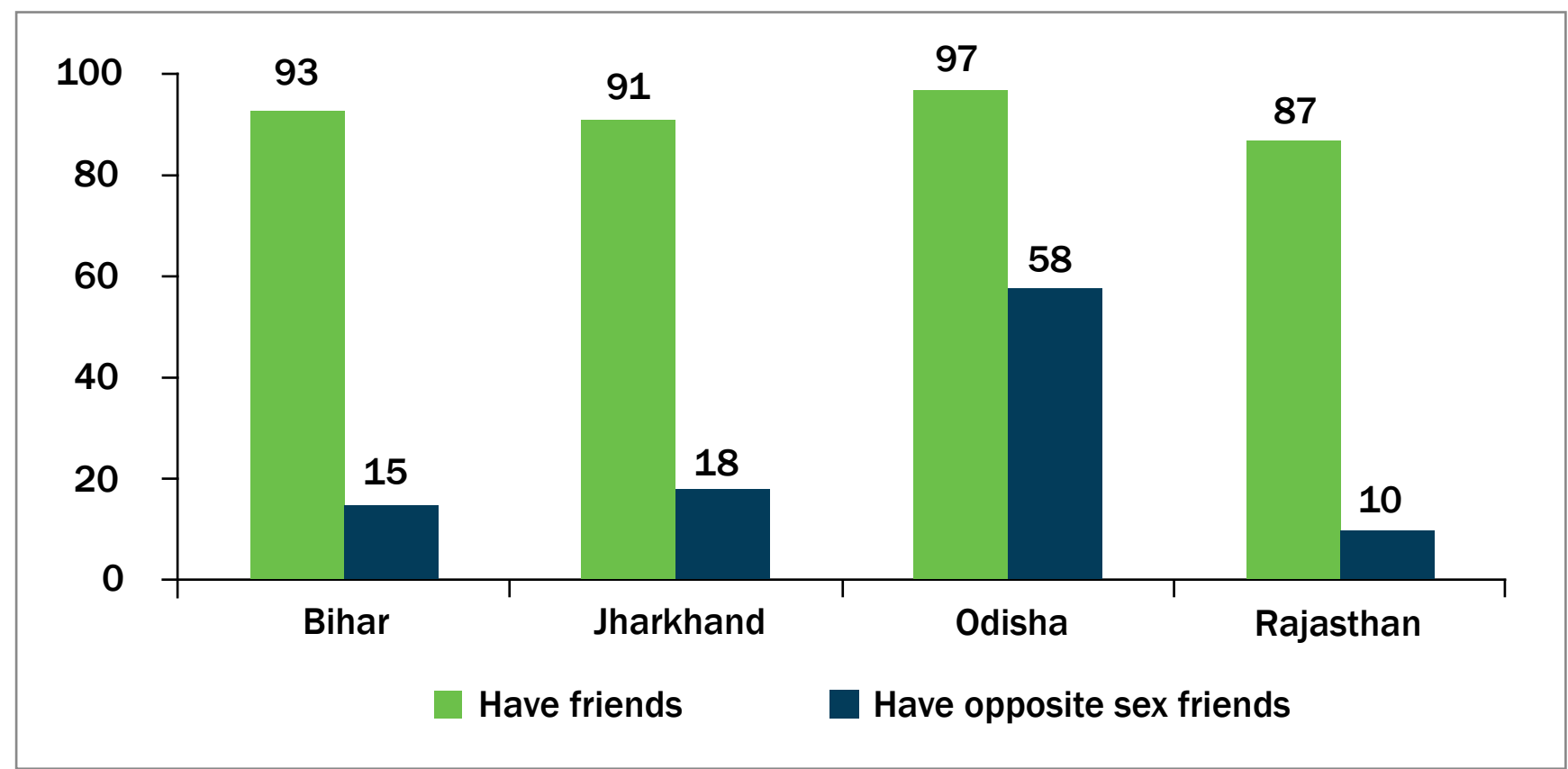




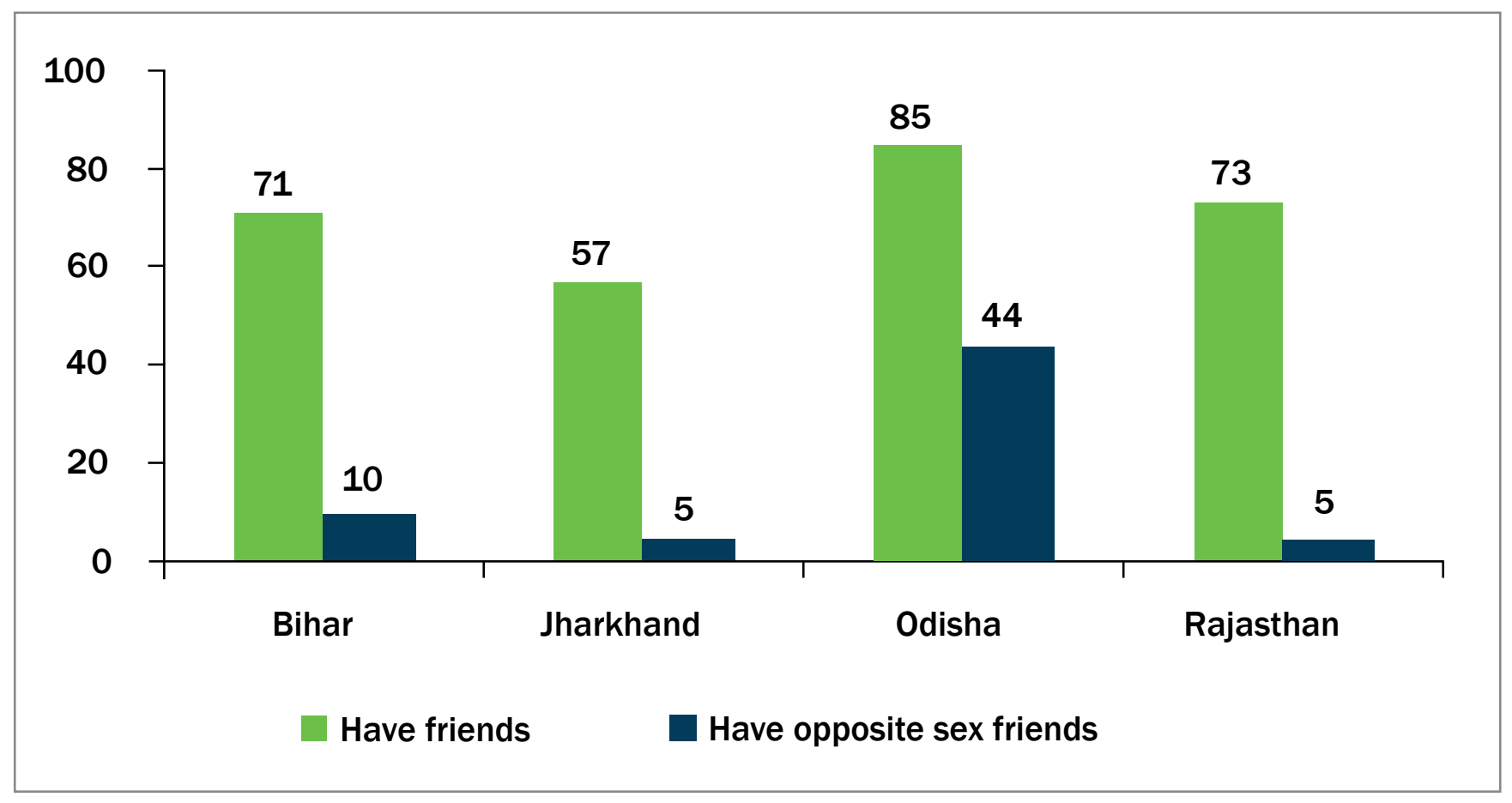

FIGURE 4. Percentage of adolescent girls having media exposure and access to mobile phones

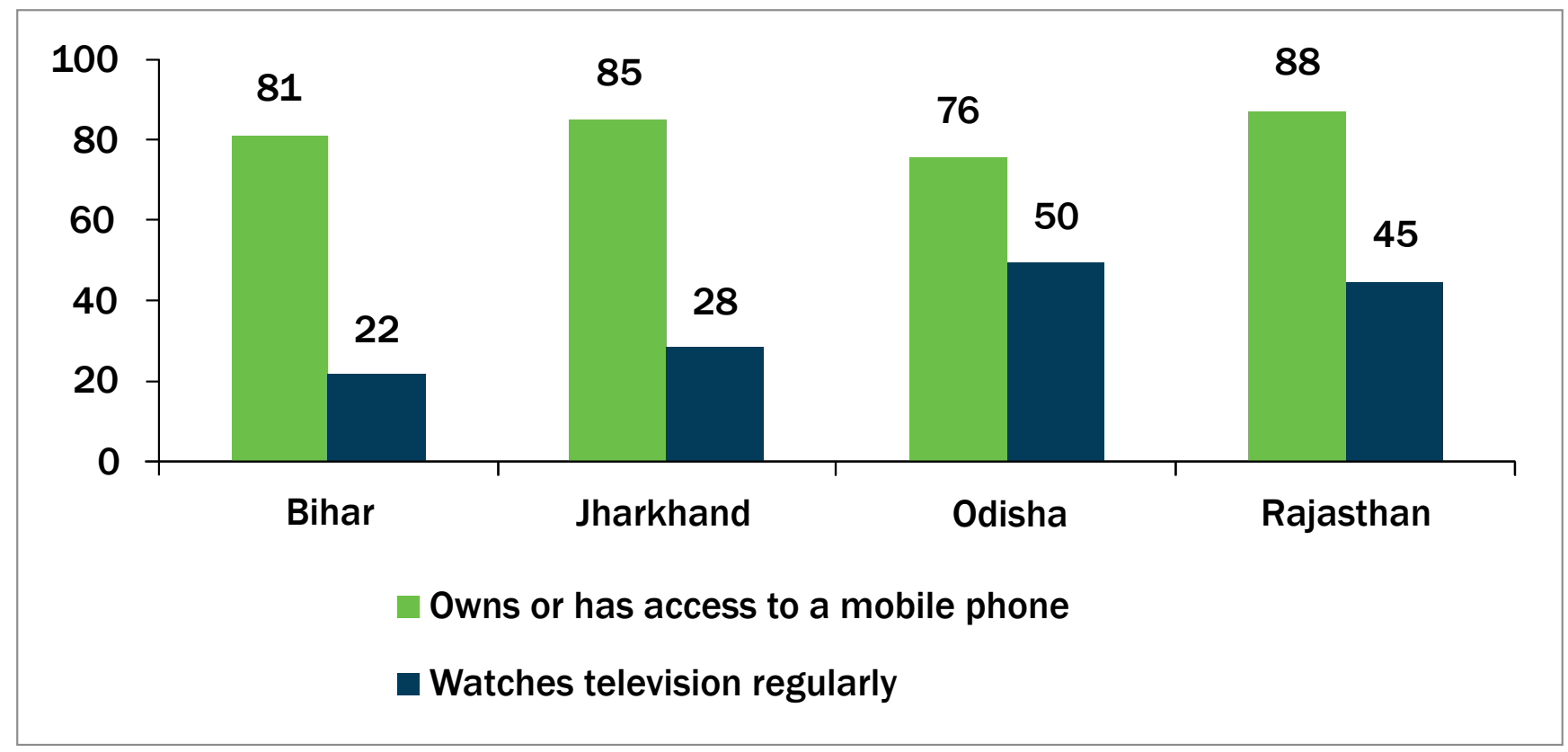

\section{Social life, agency, and gender-role attitude}

In the baseline survey, we asked girls whether they could go out after sunset, their experience of verbal harassment, and their participation in cultural activity in the school/ community in the three-month period prior to the interview. Findings, presented in Table 13, show that only a few girls were allowed to go out after sunset-only $14 \%$ in Jharkhand, about 30\% in Odisha and Rajasthan, and more than 40\% in Bihar. Participation in cultural activity in the three months prior to the baseline interview was also limited across all four states, ranging from 5\%-15\%. Finally, a considerable number of girls in Bihar (25\%), Jharkhand (24\%), and Odisha (38\%) and a significant minority of girls in Rajasthan (14\%) reported that they have had experience of verbal harassment at home or outside. 
TABLE 13. Percentage of adolescent girls who are allowed to go outside the home after sunset, experienced harassment, and participated in cultural activity in the school/community in the past 3 months

\begin{tabular}{|l|c|c|c|c|}
\hline Mobility (\%) & Bihar & Jharkhand & Odisha & Rajasthan \\
\hline $\begin{array}{l}\text { Allowed to go outside the home } \\
\text { after sunset }\end{array}$ & 43.1 & 14.4 & 30.9 & 30.0 \\
\hline $\begin{array}{l}\text { Participated in cultural activity in } \\
\text { school/community in the past 3 } \\
\text { months }\end{array}$ & 7.6 & 4.5 & 15.1 & 6.2 \\
\hline $\begin{array}{l}\text { Experienced verbal harassment } \\
\text { (either at home or outside) }\end{array}$ & 25.3 & 23.7 & 38.0 & 13.7 \\
\hline Number of respondents & 754 & 731 & 721 & 776 \\
\hline
\end{tabular}

TABLE 14. Percentage of adolescent girls who reported having any savings and owning an account

\begin{tabular}{|l|c|c|c|c|}
\hline Savings indicator (\%) & Bihar & Jharkhand & Odisha & Rajasthan \\
\hline $\begin{array}{l}\text { Have personal cash savings that the } \\
\text { girl can keep in case of emergency/ } \\
\text { future plans }\end{array}$ & 38.5 & 53.4 & 37.3 & 34.3 \\
\hline Ownership of a bank/post office account & 47.5 & 65.8 & 58.0 & 51.8 \\
\hline In own (respondent's) name & 1.1 & 1.5 & 1.3 & 1.0 \\
\hline Jointly with someone else & 0.3 & 0.4 & 0.0 & 0.1 \\
\hline Both & 754 & 731 & 721 & 776 \\
\hline Number of respondents & & \multicolumn{3}{|l|}{} \\
\hline
\end{tabular}

TABLE 15. Percentage of adolescent girls by indicators of attitude toward violence against women and girls, and gender-roles attitudes

\begin{tabular}{|c|c|c|c|c|}
\hline Attitude. Agrees that: & Bihar & Jharkhand & Odisha & Rajasthan \\
\hline \multicolumn{5}{|c|}{ Attitude toward violence against women and girls } \\
\hline $\begin{array}{l}\text { There are times when a woman } \\
\text { deserves to be beaten }\end{array}$ & 36.1 & 32.8 & 17.8 & 13.1 \\
\hline $\begin{array}{l}\text { A woman should tolerate violence in } \\
\text { order to keep her family together }\end{array}$ & 68.8 & 58.0 & 77.5 & 35.6 \\
\hline $\begin{array}{l}\text { When a woman is raped, it is usually } \\
\text { her fault for being in that situation }\end{array}$ & 45.5 & 48.4 & 10.9 & 38.4 \\
\hline \multicolumn{5}{|l|}{ Gender-role attitudes } \\
\hline $\begin{array}{l}\text { Boys are allowed to say no in an } \\
\text { arranged marriage }\end{array}$ & 68.2 & 66.6 & 63.4 & 66.0 \\
\hline $\begin{array}{l}\text { Girls are allowed to say no in an } \\
\text { arranged marriage }\end{array}$ & 36.9 & 27.4 & 44.2 & 50.1 \\
\hline $\begin{array}{l}\text { It is a woman's responsibility to } \\
\text { avoid getting pregnant }\end{array}$ & 38.7 & 43.8 & 42.0 & 31.8 \\
\hline $\begin{array}{l}\text { A woman's most important role is to } \\
\text { take care of her home and cook for } \\
\text { her family }\end{array}$ & 91.3 & 92.5 & 87.1 & 77.1 \\
\hline $\begin{array}{l}\text { A woman should always obey her } \\
\text { husband }\end{array}$ & 90.5 & 83.5 & 62.4 & 85.1 \\
\hline Number of respondents & 754 & 731 & 721 & 776 \\
\hline
\end{tabular}

Note: These items were modified from the Gender-Equitable Men (GEM) Scale (Pulerwitz and Barker 2008). 
TABLE 16. Percentage of adolescent girls affiliated with any groups

\begin{tabular}{|l|c|c|c|c|}
\hline Group membership & Bihar & Jharkhand & Odisha & Rajasthan \\
\hline $\begin{array}{l}\text { Adolescent groups (KSY/SABLA/ } \\
\text { NGO sponsored) }\end{array}$ & 6.2 & 2.9 & 2.9 & 1.7 \\
\hline Youth group (NYKS/NGO sponsored) & 0.1 & 0.3 & 0.0 & 0.0 \\
\hline Sports club & 0.0 & 0.5 & 0.1 & 0.0 \\
\hline Other & 1.3 & 0.1 & 0.7 & 0.8 \\
\hline Not involved in any group & 83.3 & 81.3 & 81.1 & 73.1 \\
\hline Don't know about such groups & 10.6 & 15.3 & 15.4 & 25.3 \\
\hline Number of respondents & 754 & 731 & 721 & 776 \\
\hline
\end{tabular}

\section{Access to money}

Table 14 highlights that about two-fifths of the adolescent girls from Bihar (39\%) and Odisha (37\%) have access to personal cash savings that they can use in case of emergency/ future plans, while about one-third from Rajasthan (34\%) reported so. Interestingly, in Jharkhand, many more adolescent girls compared to other states reported having access to personal cash savings (53\%). The baseline survey also inquired as to whether adolescent girls owned any account in a bank or a post office. Findings show that half or more of the adolescent girls across all the states owned an account in a bank or post office-highest in Jharkhand (68\%) and lowest in Bihar (49\%), and in all states most of the accounts are in the girl's own name. It is to be noted here that many of these accounts may have been opened by the school for transfer of benefits, for example for scholarships.

\section{Attitudes toward violence and gender-role attitudes}

Adolescent girls' gender-role attitudes can pose a challenge to their aspiration and empowerment. Adolescent girls were asked about their attitude toward violence against women and girls as well as roles of women versus men in society. Baseline findings presented in Table 15 show that a significant proportion of adolescent girls displayed inegalitarian attitudes and many condoned violence against women and girls. As for their attitudes toward violence against women and girls, the majority of the girls from Bihar, Jharkhand, and Odisha (58\%-78\%) and about a third from Rajasthan (36\%) agreed that a woman should tolerate violence to keep her family together. On two other indicators, many fewer girls condoned violence against women. For example, $33 \%-36 \%$ of girls from Bihar and Jharkhand agreed that there are times when women deserve to be beaten, and much lower-13\%-18\% of girls from Rajasthan and Odisha also believed so. On gender roles, of the five indicators presented here, on two related to household duties and power roles, adolescent girls from all four states overwhelmingly displayed inegalitarian attitudes. For example, as many as 91\%-93\% from Bihar and Jharkhand and 77\%-87\% from Odisha and Rajasthan believed that a woman's most important role is to take care of her home and cook for her family. On the issue of marriage, about two-thirds of girls displayed inegalitarian attitudes-they believed boys are allowed to say no to a parent-arranged marriage and girls don't have such agency.

\section{Group membership}

The baseline survey also asked girls whether they were affiliated with or a member of any association/club/group/NGO (for example, Kishori Shakti Yojana [KSY]/SABLA groups for girls, clubs formed under the Nehru Yuva Kendra Sangathan [NYKS clubs], sports clubs, self-help groups, or any other groups sponsored by NGOs or the government).

Table 16 presents data on adolescent girls' participation in such groups. Overall, only very limited numbers of girls reported that they were members of any group as described above-2\%-6\% so reported with the highest proportion in Bihar. A quarter of girls from Rajasthan and $11 \%-16 \%$ in the other three states were not even aware of such groups. 
68.8 shar

58.0 mamanara

Girls agree that a woman should

77.5 odisna

tolerate violence

to keep her family

together (\%)

35.6 Rajasthan

90.5 shar

83.5 hararkhand

Girls agree that a

woman should always

62.4 odisha

obey her husband (\%)

85.1 Rajasthan 


\section{Sexual and Reproductive Health}

Access to sexual and reproductive health information and services is central to the "Marriage: No Child's Play" intervention program to delay marriage. In 2014, the Government of India launched Rashtriya Kishor Swasthya Karyakram (RKSK), and improving the sexual and reproductive health of adolescents is one of the six strategic priority areas under that program. In this section, we look at the awareness of HIV/AIDS, STIs other than HIV/AIDS, contraception, and pregnancy-related matters. We also probe on knowledge about legal age at marriage, adverse effect of marriage before age 15, access to programs like comprehensive sexuality education (CSE), and conditional cash transfer (CCT). Some questions were asked of all girls aged 12-19 and some were asked only of girls aged 15-19 because they were potentially sensitive (e.g., about contraception or pregnancy-related matters).

\section{Awareness of sexual and reproductive health matters}

The baseline survey probed adolescent girls aged 12-19 who had started menstruating as to whether they knew about menstruation before it began. Findings reveal that about one-fifth of the adolescent girls in the sample had not yet started menstruating (18\%). Among those who had started menstruating, only about one-third (29\%) knew about menstruation before it began for them (15\%, 24\%, $54 \%$, and $23 \%$, respectively in Bihar, Jharkhand, Odisha, and Rajasthan, not shown in table).

Table 17 presents the findings on awareness of various reproductive and sexual health related matters. Adolescent girls were asked whether they had heard about HIV/AIDS. Interestingly about half of the adolescent girls from Odisha (51\%) reported that they had heard about HIV/AIDS, while only $8 \%-16 \%$ of girls from the other states reported so. This high level of awareness of HIV/AIDS in Odisha compared to other states is possibly due to the high prevalence of HIV/ AIDS in some districts of Odisha, including in our study districts. Among the adolescents aged 12-19, comprehensive knowledge about HIV/AIDS was very low, 1\%-2\% in Bihar, Jharkhand, and Rajasthan, and 7\% in Odisha, revealing the large gap between simple awareness and crucial in-depth knowledge.
Adolescent girls aged 15-19 were asked whether they had heard about infections other than HIV that people can get from sexual contacts. Findings show that about one in eight girls from Bihar, Jharkhand, and Rajasthan (13\%, 12\%, and $13 \%$ respectively) and only $5 \%$ in Odisha had heard about STIs other than HIV despite their higher knowledge about HIV.

Among adolescent girls aged 12-19 from the three high child-marriage-prevalence states (Bihar, Jharkhand, and Rajasthan), awareness about legal minimum age at marriage for girls was high but far from universal. Table 17 reveals that about three-fifths of the adolescent girls aged 12-19 from Bihar (63\%) and Jharkhand (58\%) and about fourfifths of the girls in Rajasthan (79\%) were aware that 18 is the legal minimum age at marriage for females. Awareness about at least three adverse effects of marrying before age 15 was very low: 13\%-17\% in Bihar/Jharkhand/Rajasthan and $44 \%$ in Odisha. Adolescent girls aged 15-19 married or unmarried were also asked about their awareness of contraception. Table 17 shows that among all the modern methods, only awareness about female sterilization was near universal, underscoring programmatic bias for sterilization. Lack of knowledge about methods most likely to be used by adolescents-condoms, pills, and emergency contraception (EC)-is a matter of concern. For example, only about 36\%-59\% heard about condoms, and an even lower proportion of girls-15\%-29\%-heard about emergency contraception. Correct use of oral contraceptive pills, condoms, or EC was known to even fewer girls. For example, $17 \%-26 \%$ knew how to use condoms, and 6\%-19\% knew correct usage of pills. Table 17 also highlights that awareness about menstruation was almost universal but awareness of pregnancy-related matters was limited. Only about one-quarter to one-third of girls knew that a woman can get pregnant at first sexual intercourse.

Overall about three-fifths (58\%) of the adolescent girls aged 12-19 reported parents as the leading source of information on puberty and reproductive-health-related matters (not shown in table). 
TABLE 17. Percentage of adolescent girls' aged 12-19 who have heard of and have comprehensive awareness of HIV/AIDS, STIs, contraceptive methods, child marriage, and pregnancy-related matters

\begin{tabular}{|c|c|c|c|c|}
\hline Awareness indicators (\%) & Bihar & Jharkhand & Odisha & Rajasthan \\
\hline \multicolumn{5}{|l|}{ HIV awareness } \\
\hline Heard about HIV/AIDS & 11.4 & 7.9 & 50.8 & 16.1 \\
\hline Have comprehensive knowledge of HIV ${ }^{1}$ & 1.5 & 0.8 & 7.1 & 1.2 \\
\hline \multicolumn{5}{|l|}{ Marriage-related awareness } \\
\hline $\begin{array}{l}\text { Knows that } 18 \text { is the legal minimum age at } \\
\text { marriage for females }\end{array}$ & 62.6 & 58.3 & 54.7 & 79.3 \\
\hline $\begin{array}{l}\text { Knows at least three adverse effects of } \\
\text { marrying before age } 15\end{array}$ & 17.4 & 13.1 & 49.2 & 16.5 \\
\hline Number of respondents aged 12-19 & 754 & 731 & 721 & 776 \\
\hline \multicolumn{5}{|l|}{ STI awareness } \\
\hline Heard of STIs other than HIV/AIDS & 12.6 & 11.8 & 4.7 & 13.1 \\
\hline \multicolumn{5}{|l|}{ Contraception awareness } \\
\hline \multicolumn{5}{|l|}{ Aware of: } \\
\hline Oral contraceptive pills & 52.3 & 57.3 & 74.9 & 65.0 \\
\hline Emergency contraceptive pills & 14.5 & 14.4 & 28.8 & 16.2 \\
\hline Condoms & 36.4 & 47.1 & 58.8 & 44.8 \\
\hline IUDs & 23.8 & 25.4 & 23.5 & 22.2 \\
\hline Injections & 38.4 & 44.2 & 32.3 & 41.0 \\
\hline Female sterilization & 96.7 & 95.8 & 94.2 & 94.0 \\
\hline Male sterilization & 63.3 & 61.5 & 43.5 & 47.2 \\
\hline \multicolumn{5}{|l|}{ Have knowledge of: } \\
\hline Correct use of oral contraceptive pills & 6.9 & 9.7 & 18.8 & 6.0 \\
\hline Correct use of emergency contraceptive pills & 3.3 & 0.8 & 7.0 & 0.9 \\
\hline Correct use of condoms & 16.7 & 19.1 & 25.6 & 17.3 \\
\hline \multicolumn{5}{|l|}{ Awareness of pregnancy-related matters } \\
\hline $\begin{array}{l}\text { That a women can get pregnant at first sexual } \\
\text { intercourse }\end{array}$ & 34.0 & 30.4 & 30.0 & 25.3 \\
\hline $\begin{array}{l}\text { When during the cycle a woman can get } \\
\text { pregnant }\end{array}$ & 10.4 & 12.8 & 6.1 & 8.4 \\
\hline Number of respondents aged 15-19 & 365 & 382 & 430 & 451 \\
\hline
\end{tabular}

1. Comprehensive awareness of HIV/AIDS for 15-19-year-old adolescents includes: (1) identifying two major ways of preventing HIV (using condoms always and limiting sex to one partner); (2) rejecting three common misconceptions about HIV transmission (that HIV can be transmitted through mosquito bites, sharing food with a person who has HIV, and hugging someone who has HIV); and (3) knowing that a healthy-looking person can be HIV-positive. Comprehensive awareness of HIV/AIDS for 10-14-year-old adolescents includes: (1) rejecting three common misconceptions about HIV transmission (that HIV can be transmitted through mosquito bites, sharing food with a person who has HIV, and hugging someone who has HIV); and (2) knowing that a healthy-looking person can be HIV-positive. 


\subsection{Bihar \\ 1.0 Jharkhand Girls have \\ 71 knowledge about \\ 7.1 Odisha HIV/AIDS (\%) \\ 1.2 Rajasthan}

0.0 shar

0.8 Jharkhand Girls ever sought

services from an

0.7 Odisha $\quad \begin{aligned} & \text { adolescent-friendly } \\ & \text { health clinic (\%) }\end{aligned}$

0.2 Rajasthan 


\section{Access to Programs}

Table 18 highlights that access to comprehensive sexuality education (CSE) was limited. In the baseline survey, adolescent girls were asked whether they ever attended any training or program or course on CSE organized by the government or NGOs. Findings show that only about $8 \%-12 \%$ of girls in Bihar, Jharkhand, and Rajasthan and $21 \%$ in Odisha had ever received CSE.

Girls were also asked whether they heard about conditional cash transfer (CCT) programs--programs from which one gets an amount of money after a certain period of time if they meet some specific criteria set by the program. About one in three adolescent girls from Bihar, Jharkhand, and Rajasthan (34\%, 36\%, and 34\%, respectively) heard about CCT programs, however in Odisha only $4 \%$ heard about such programs. Very few girls actually received the benefits of a CCT program-1\%-3\% in Bihar, Jharkhand, and Rajasthan. Adolescent girls aged 15-19 were also asked if they heard about or accessed services from an adolescent-friendly health clinic. Overall, negligible numbers had heard about $(2 \%-6 \%)$ or accessed $(<1 \%)$ services from an adolescentfriendly health clinic (Table 18).

TABLE 18. Percentage of adolescent girls aged 12-19 who have access to comprehensive sexuality education

\begin{tabular}{|l|c|c|c|c|}
\hline $\begin{array}{l}\text { Access to comprehensive sexuality } \\
\text { education (\%) }\end{array}$ & Bihar & Jharkhand & Odisha & Rajasthan \\
\hline $\begin{array}{l}\text { Ever received comprehensive } \\
\text { sexuality education (training } \\
\text { program/course) }\end{array}$ & 11.5 & 9.3 & 20.7 & 8.4 \\
\hline $\begin{array}{l}\text { Have heard about conditional cash } \\
\text { transfer schemes (CCTs) }\end{array}$ & 34.0 & 36.0 & 4.0 & 34.0 \\
\hline Beneficiary of CCT & 2.0 & 1.1 & 0.3 & 3.0 \\
\hline $\begin{array}{l}\text { Number of respondents aged } \\
12-19\end{array}$ & 754 & 731 & 721 & 776 \\
\hline $\begin{array}{l}\text { Have heard about adolescent- } \\
\text { friendly health clinics }\end{array}$ & 6.6 & 6.0 & 4.4 & 0.2 \\
\hline $\begin{array}{l}\text { Ever sought services from } \\
\text { adolescent-friendly health clinics }\end{array}$ & 0.0 & 0.8 & 0.7 & 451 \\
\hline $\begin{array}{l}\text { Number of respondents aged } \\
15-19\end{array}$ & 365 & 382 & 430 & 0.2 \\
\hline
\end{tabular}

${ }^{1}$ Any government scheme that puts money into a girl's account and allows her to use the money when she reaches a certain age or completes a certain level of education and remains unmarried. 


\section{Premarital Relations, Marriage, and Motherhood}

Adolescent girls in India are engaged in premarital sex despite taboos on intimate interaction with the opposite sex and romantic relationship formation (IIPS and Population Council 2010). This section highlights findings on the prevalence of opposite sex intimate relationships and sexual experiences in these relationships among adolescent girls in the four study states.

We asked adolescent girls aged 15-19 whether they ever had a boyfriend and, if yes, the extent of physical intimacy in these relationships. Table 19 reveals a large amount of variation in the proportion of adolescent girls reporting having a boyfriend--between one in six (16\%-17\%) in Bihar and Jharkhand, and about one-third in Odisha (33\%). The lowest proportion was reported in Rajasthan-just about one in ten (9\%). Reporting of sexual intercourse in romantic partnerships was low but it ranged from $12 \%-39 \%$ across the four states. Bihar had the highest proportion of girls in relationships reporting having sexual intercourse with their partner.

\section{Age at marriage and cohabitation}

Table 20 shows that about one-quarter of the adolescent girls aged 12-19 from Jharkhand (26\%), 13.4\% from Bihar, and only 1 in 13 from Odisha and Rajasthan (8\%) were married and living with their husband at the time of interview. These percentages were much higher for girls aged 15-19 (13\%-49\%), with Jharkhand having the highest proportion of girls 15-19 currently married at $49 \%$. Consequently, there is large variation in average age at marriage within these four study states. For example, average age

TABLE 19. Percentage of adolescent girls aged 15-19 reporting premarital sexual relationships

\begin{tabular}{|l|c|c|c|c|}
\hline $\begin{array}{l}\text { Premarital romantic and sexual } \\
\text { relationships }\end{array}$ & Bihar & Jharkhand & Odisha & Rajasthan \\
\hline $\begin{array}{l}\text { Ever had an opposite-sex romantic } \\
\text { partner }\end{array}$ & 16.2 & 17.3 & 33.3 & 8.9 \\
\hline Number of respondents aged 15-19 & 365 & 382 & 430 & 451 \\
\hline $\begin{array}{l}\text { Ever had sexual relations with a } \\
\text { romantic partner (\%) }\end{array}$ & 39.0 & 24.2 & 12.0 & $(12.5)$ \\
\hline $\begin{array}{l}\text { Number reporting a romantic } \\
\text { relationship }\end{array}$ & 59 & 66 & 143 & 40 \\
\hline
\end{tabular}

TABLE 20. Percentage of girls ever married, currently married, age at marriage, and cohabitation

\begin{tabular}{|l|c|c|c|c|}
\hline $\begin{array}{l}\text { Marital status and age at marriage and } \\
\text { cohabitation }\end{array}$ & Bihar & Jharkhand & Odisha & Rajasthan \\
\hline $\begin{array}{l}\text { Percentage of girls aged 12-19 } \\
\text { currently married }\end{array}$ & 13.4 & 26.4 & 7.5 & 7.5 \\
\hline Number of respondents & 754 & 731 & 721 & 776 \\
\hline $\begin{array}{l}\text { Percentage of girls aged 15-19 } \\
\text { currently married }\end{array}$ & 26.9 & 48.7 & 12.6 & 12.9 \\
\hline Number of respondents aged 15-19 & 365 & 382 & 430 & 451 \\
\hline Median age at first marriage & 15.0 & 15.0 & 17.0 & 13.0 \\
\hline Number of married respondents & 127 & 203 & 55 & 181 \\
\hline Median age at first cohabitation & 15.0 & 15.0 & 17.0 & 17.0 \\
\hline $\begin{array}{l}\text { Number of married respondents who } \\
\text { had started living with husband }\end{array}$ & 103 & 201 & 55 & 61 \\
\hline
\end{tabular}


at marriage in Odisha is 17, compared to 15 in Bihar and Jharkhand, and only 13 in Rajasthan. However, a very different trend was observed in average age at cohabitation-on average a girl from Rajasthan starts living with her husband at age 17 after spending 4 years in her parents' home after marriage. No difference between age at marriage and age at cohabitation was found in the rest of the states, a possible indication that with the rising age at marriage, the culture of gauna is waning in these states.

Among girls aged 15-19, between 13 and 18 percent of girls in Bihar, Jharkhand, and Rajasthan and no girl from Odisha were married by age 15 (Figure 5). Among girls aged 18-19, about three-fifths (63\%) from Jharkhand were married before age 18, while about half in Bihar and about two-fifths (42\%) in Rajasthan reported so. Early marriage was least prevalent in Odisha-only about one in seven (15\%) girls aged 18-19 got married before age 18.

\section{Contraceptive use within marriage}

Table 21 shows the state differential in current use of any contraceptive method by adolescents. Findings show that among those who had begun cohabiting with their husband, current use of any contraceptive method and any modern contraceptive method was very limited. In Jharkhand, Odisha, and Rajasthan only between 9 and 12 percent of the girls were using any modern methods and this percentage was very low for Bihar (3\%). Condom use was correspondingly limited (2-7\%).

\section{Reproductive history and motherhood}

Table 22 reveals that among those who had begun cohabiting, there was variation across states in the percentage of girls who were ever pregnant-with 36 percent of girls from Rajasthan, between 54 and 58 percent of girls from Odisha and Jharkhand, and 66 percent of girls from Bihar reporting so. Much less variation was reported in the proportion currently pregnant-11\%-16\% reported being pregnant at the time of the interview. While between $41 \%$ and $47 \%$ of adolescents were reported to have begun childbearing in Bihar, Jharkhand, and Odisha, only $22 \%$ reported so in Rajasthan. The mean number of children ever born was less than one (0.8) in three out of four states and one in Jharkhand. While we haven't collected data for the extent of pregnancy loss, findings seem to indicate that the large differences between states may be explained by the fact that prevalence of unintended pregnancy and induced abortion was likely higher in Bihar compared to Rajasthan. This is also consistent with the findings presented in Table 21 that use of modern contraceptives is only $3 \%$ in Bihar compared with $9 \%$ in Rajasthan.

FIGURE 5. Percentage of girls married before age 15 and 18 *

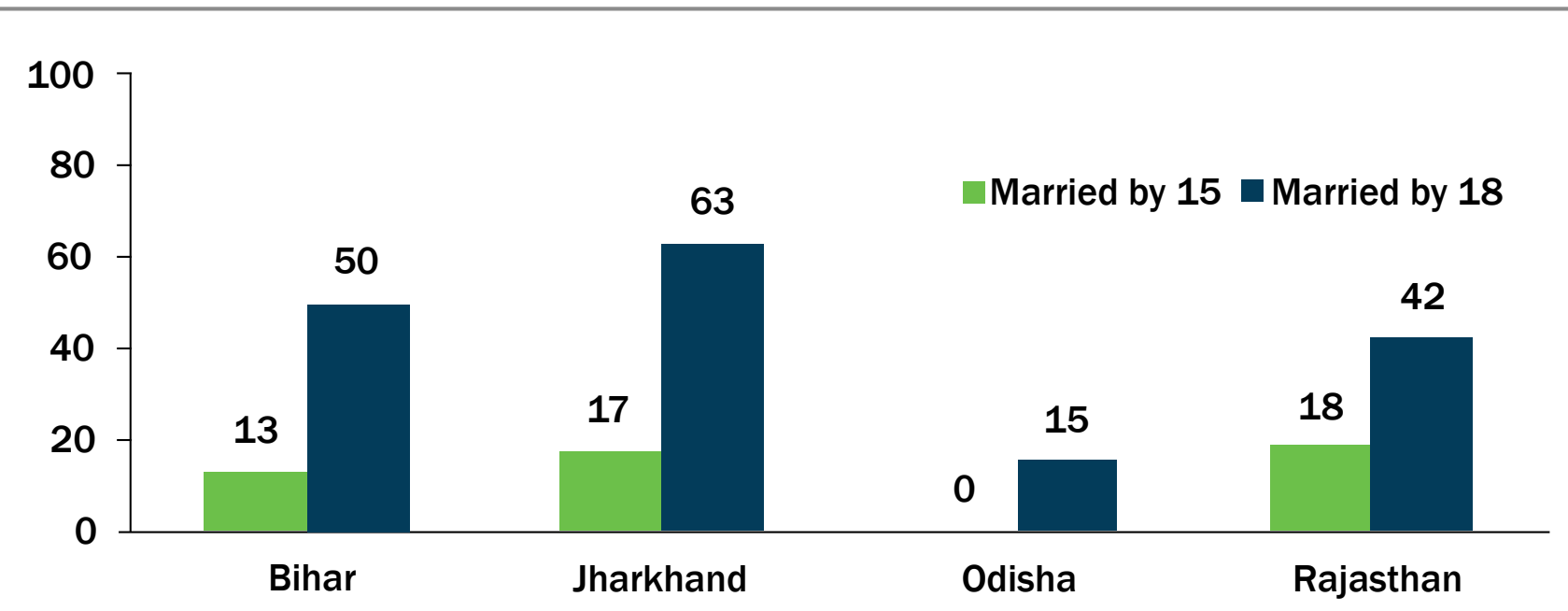

*Note: Among all girls aged 15-19 and among those aged 18-19, respectively. 
TABLE 21. Current use of contraception within marriage

\begin{tabular}{|c|c|c|c|c|}
\hline Current use of contraception & Bihar & Jharkhand & Odisha & Rajasthan \\
\hline Any method & 11.2 & 23.1 & 18.5 & 17.2 \\
\hline Any modern method & 3.1 & 12.4 & 9.3 & 8.6 \\
\hline Condom use & 2.0 & 7.0 & 3.7 & 5.2 \\
\hline $\begin{array}{l}\text { Number of respondents who have } \\
\text { begun cohabiting }\end{array}$ & 98 & 186 & 54 & 58 \\
\hline
\end{tabular}

TABLE 22. Percentage of married girls aged 15-19 who had begun cohabiting and their reproductive history

\begin{tabular}{|c|c|c|c|c|}
\hline Reproductive history & Bihar & Jharkhand & Odisha & Rajasthan \\
\hline Ever been pregnant & 66.3 & 58.1 & 53.7 & 36.2 \\
\hline Currently pregnant & 16.3 & 16.1 & 11.1 & 12.1 \\
\hline Have one or more living children & 45.9 & 46.8 & 40.7 & 22.4 \\
\hline Mean children ever born & 0.8 & 1.0 & 0.8 & 0.8 \\
\hline $\begin{array}{l}\text { Number of respondents who have } \\
\text { begun cohabiting }\end{array}$ & 98 & 186 & 54 & 58 \\
\hline
\end{tabular}

\subsection{Bhar}

$58.3^{\text {mantanama }}$

54.7 odsisa

79.3 rasaranan

17.4 enar

13.1 nnarkhand

49.2 odstas

16.5 rasastan
Girls can correctly identify the legal age at marriage for females (18) (\%)

Girls can name at least three adverse effects of early marriage (before 15 years) (\%)
3.9 shar

4.8 Jharkhand

(in years) among

6.0 Odisha married girls

29 Rajasthan 


\section{Discussion}

Findings from the baseline data give us important information about the lives of adolescent girls in these communities and may have important implications for programs addressing adolescents. For example, we found that although school enrollment was nearly universal, retaining girls in school was a challenge with only about three-fifths (55\%$63 \%$ ) of adolescent girls aged 12-19 in school at the time of the survey. A key lesson for programs is to focus on steps that can keep girls in school longer. Among married girls, retention in school was further limited, as expected. Among those who had ever been to school, the leading reason for discontinuation was the respondent's lack of interest in studies followed by getting married in Jharkhand (31\%), house-related work in Bihar (26\%), economic reasons in Odisha (40\%), and school-related reasons in Rajasthan (31\%). Findings also underscored poor learning outcomes for girls, which might also be a reflection of poor quality of schooling.

Engagement in wage work was not uncommon among this group; even among younger adolescent girls (12-14 years) $15 \%-23 \%$ reported that they had ever worked for wages and $4 \%-11 \%$ had worked for wages in the month before the survey. Among the older adolescents (15-19 years), over one-quarter to one-half were ever engaged in wage work and $7 \%-24 \%$ in the last month before the survey. Occupational profiles of those who were engaged in wage work show that farming/agricultural work and unskilled daily wage work were the leading occupations among the adolescent girls. Opportunity for attending a vocational training program was very limited among the girls, with about $4 \%-12 \%$ of the girls ever attending a vocational training program. Interestingly, unmet need for such courses is very high-with more than three-quarters of girls expressing interest in joining a vocational training course, if supported. However, in all states, over 9 out of 10 girls opted for traditional trades for vocational training-tailoring, handicrafts/ embroidery, beauty parlor, etc. Few opted for more modern trades like computer training. This information is crucial for the program as they prepare to make connections between girls in the intervention areas and government skillsbuilding programs.
Important findings for programs regarding girls' social life include that most adolescent girls have at least one friend (87\%-97\% among unmarried girls, and 57\%-85\% among married girls), have limited mobility after sunset (less than two out of five girls in any state were allowed to go out after sunset), and have access to mobile phones (76\%-88\% own or have access). However, regular exposure to mass media was limited (only $22 \%-50 \%$ watched television regularly). Baseline findings also show that half or more girls across all the states owned an account in a bank or post office. Findings suggest that programs also need to focus on attitudes displayed by the girls on violence and gender roles, as the majority of girls condoned violence against women and also displayed inegalitarian attitudes on a number of indicators. It is very important to note that so far very few girls $(2 \%-6 \%)$ were part of any adolescent group and hence programs need to make an effort to convince girls, and their gatekeepers, that participation in the program is worthwhile.

Findings also highlight limited awareness about reproductive and sexual health among adolescent girls, with only about one-third (29\%) knowing about menstruation before it started and $1 \%-7 \%$ having comprehensive knowledge about HIV/AIDS. Even awareness about pregnancy and contraception was limited: only about one-quarter to one-third of adolescent girls knew that a woman could get pregnant at first sexual intercourse. Findings underscore that programs certainly need to work on improving knowledge of reproductive health matters and establish themselves as a major source of such information to adolescents in the intervention areas. Currently, parents are the predominant source of information (58\%). Unfortunately, government programs for providing comprehensive sexuality education (CSE), intended to improve adolescents' knowledge, have limited reach ( $8 \%-21 \%$ received CSE). Negligible numbers had heard of $(2 \%-6 \%)$ or accessed (<1\%) services from government adolescent-friendly health clinics.

Finally, baseline findings show that a significant minority of adolescent girls do become sexually active before marriage despite societal taboo. Among girls who had a romantic relationship (before marriage), 12\%-39\% across the four states had sexual relationships with their boyfriends. Baseline findings also confirm child marriage is still happening 
in the four study states, with median age at first marriage ranging from 13-17 years. Notably, early marriage was least prevalent in Odisha where only about one in seven (15\%) girls aged 18-19 years got married before age 18 . Within marriage, contraceptive use was limited and any modern method use was low (3\%-12\%) across all four states. In three states, nearly half of the girls who were cohabiting with their husband already had one or more living children; only in Rajasthan one-quarter of girls reported so. 


\section{References}

Ghosh, B. 2011. "Child marriage, society and the law: A study in a rural context in West Bengal, India." International Journal of Law, Policy and the Family 25(2): 199-219.

HAQ Centre for Child Rights. n.d. Child Marriage in India: Achievements, Gaps and Challenges-Response to Questions for $\mathrm{OHCHR}$ Report on Preventing Child, Early and Forced Marriages for Twenty-sixth Session of the Human Rights Council. Accessed 23 May 2016. http://www.ohchr.org/Documents/Issues/Women/ WRGS/ForcedMarriage/NGO/HAQCentreForChildRights1.pdf.

International Institute for Population Sciences (IIPS). 2016. National Family Health Survey-4, 2015-2016, India Factsheet, Mumbai: IIPS.

International Institute for Population Sciences (IIPS) and Population Council. 2010. Youth in India, Situation and Needs 2006-07. Mumbai: IIPS.

Kanesathasan, A., L.J. Cardinal, E. Pearson, et al. 2008. Catalyzing Change: Improving Youth Sexual and Reproductive Health through DISHA, an Integrated Program in India. Washington, DC: International Center for Research on Women (ICRW).

Ministry of Human Resource Development. n.d. Kasturba Gandhi Balika Vidalayas. Government of India: MOHRD. Accessed 20 July 2016. http://mhrd.gov.in/kasturba-gandhi-balika-vidyalayas.

Ministry of Human Resource Development, Department of School Education and Literacy. n.d. National Scheme for Incentives to Girls for Secondary Education. Government of India. MOHRD. Accessed 20 July 2016. http://mhrd.gov.in/incentives.

Ministry of Women and Child Development (MOWCD). n.d. Annual Report 2014-15. New Delhi: MOWCD, Government of India.

Nanda, P., P. Das, N. Datta, et al., 2016. Making Change with Cash? Impact of a Conditional Cash Transfer Program on Girls' Education and Age of Marriage in India, Synthesis of Findings. Washington, DC: International Center for Research on Women (ICRW). Accessed 21 June 2016. http://www.icrw.org/sites/default/files/ publications/IMPACCT_Synthesis_Webready.pdf.

National Mission for Empowerment of Women (NMEW) and the National Resource Centre for Women (NRCW), n.d. Report on Status of Implementation of Prohibition of Child Marriage Act collected from the states 2014. Ministry of Women \& Child Development, Government of India. Accessed 5 May 2016. http://nmew.gov.in/WriteReadData/I892s/PCMA\%20 FINAL-19112720.pdf.
Office of the Registrar General and Census Commissioner, India, n.d.,a. C-2 Marital status by age and sex, Census of India 2001. Accessed 9 September 2016. http://www.censusindia.gov.in/ DigitalLibrary/MFTableSeries.aspx.

Office of the Registrar General and Census Commissioner, India, n.d.,b. C-2 Marital status by age and sex, Census of India 2011. Accessed 9 September 2016. http://www.censusindia.gov. in/2011census/C-series/c-2.html.

Pande, R., K. Kurz, S. Walia, et al. 2006. Improving the Reproductive Health of Married and Unmarried Youth in India: Delaying Age at Marriage in Rural Maharashtra, India, Washington, DC: International Centre for Research on Women (ICRW).

Pulerwitz, Julie and Gary Barker. 2008. "Measuring attitudes toward gender norms among young men in Brazil: Development and psychometric evaluation of the GEM Scale," Men and Masculinities 10: 322-338.

Singh, K. 2013. Laws and Son Preference in India: A Reality Check. New Delhi: UNFPA.

UNICEF. 2014. Ending Child Marriage: Progress and Prospects. New York: UNICEF. Accessed 5 July 2016. http://data.unicef.org/ corecode/uploads/document6/uploaded_pdfs/corecode/ChildMarriage-Brochure-HR_164.pdf. 